\title{
'Held in Place': Round Barrows in the Later Bronze Age of Lowland Britain
}

\author{
By ANWEN COOPER ${ }^{1}$
}

This paper presents a systematic study of later Bronze Age practices at round barrows - features that are typically seen as emblematic of the Early Bronze Age in Britain. Examining the evidence from 87 excavated round barrows in the east of England, it adds subtlety and empirical detail to previous discussions about the changing role of funerary monuments over the course of the 2 nd millennium BC. A wide variety of activities was undertaken at existing round barrows in the later Bronze Age. Burials were added, the monuments themselves were augmented and replicated, they were often actively built into land boundary systems, and settlements were located close to them. The findings not only attest to the continued (if shifting) significance of round barrows in the later Bronze Age, they also contribute substantially to wider debates about the character of life during this period in lowland Britain - the shifting relationship between 'ritual' and 'everyday' practices, and the processes by which mobile communities began to settle down. More broadly, this investigation adds to a growing body of work that explores the multi-temporal qualities of later prehistoric landscapes.

Keywords: Round barrows, later Bronze Age, landscape archaeology, grey literature

Round barrows are, without doubt, central to understandings of the Early Bronze Age in Britain and beyond. They were a key attraction for archaeological enquiry at the inception of the discipline and continue to attract substantial research attention (see for example Woodward 2000; papers in Last 2007a; Garrow et al. 2014). On the near Continent where round barrow and subsequently urnfield building extended well into the Iron Age, researchers have understandably tended to take a longer-term approach to investigating the emergence of extensive 'barrow landscapes' (Fontijn 1996, 77; see also Roymans 1995; Gerritsen 2003; 2007; Bourgeois \& Fontijn 2008; Fokkens 2012; Bourgeois 2013; Holst et al. 2013; Van Beek \& De Mulder 2014; Løvschal 2014; 2015). In lowland Britain, meanwhile, a very different scenario has unfolded. It is widely accepted that round barrows in Wessex provided a focus for burials into the Middle Bronze Age (eg, Woodward 2000). However most later Bronze Age studies focus justifiably on

\footnotetext{
${ }^{1}$ Institute of Archaeology, University of Oxford, 34 Beaumont Street, Oxford, OX1 2PG

Email: anwen.cooper@arch.ox.ac.uk
}

explaining the emergence of a new suite of architectural and depositional practices at this time - fields, settlement remains, and metalwork deposits (eg, Bradley 2007). ${ }^{1}$ In this context, the significance of round barrows is seen simply to have waned. Evidence from over 25 years of developer-funded investigation and the findings of recent studies of later Bronze Age funerary practices (Robinson 2007; Caswell 2013) suggest that this situation requires re-examining. It is clear that in some parts of Britain at least, round barrows (old, and also sometimes new) were very much part of later Bronze Age lives.

This paper considers specifically the role of round barrows in later Bronze Age landscapes - what they did and did not do, and what people did to them. Using a case study from the east of England and drawing on wider examples, it presents a systematic examination of round barrow relationships - their associations with people and things $-c .1500-800 \mathrm{BC}^{2}$ It foregrounds the active role that round barrows played in many later Bronze Age landscapes, reveals changes in the practices associated with them, and considers these changes alongside broader developments in the evidence base for this period. In so doing 
this study casts light on a range of themes that have been central to recent research into the later Bronze Age - shifts in funerary activity, changes in people's relationships with land, the negotiation of new material repertoires (in particular metalwork), and the mingling of 'ritual' and 'everyday' practice. More broadly, this work contributes to analyses that have considered the role of social memory and the kinds of historical understandings associated with activities at round barrows (eg, Mizoguchi 1993; Garwood 2007; Garrow et al. 2014).

EMPHASISING ORIGINS: ROUND BARROWS IN EXISTING ACCOUNTS OF THE BRONZE AGE IN LOWLAND BRITAIN

As a background to this study, it is important to ask at a broad level how round barrows have been approached in existing accounts of the Bronze Age in lowland Britain. In so doing it becomes clear that an unhelpful separation has developed between Early and later Bronze Age round barrow research over at least a 20 -year period. Details of the time periods referred to throughout this paper are outlined in Table 1.

Researchers focusing on the Late Neolithic and Early Bronze Age have emphasised the complex and, at times, intimate nature of activities at round barrows in this period, foregrounding the diversity of practices concerned, examining in detail their temporal qualities, and considering the social implications of this evidence (eg, Barrett 1994; Woodward 2000; Brück 2004; Last 2007a; Garrow et al. 2014).

In brief, these studies have elicited the lengthy histories of some round barrows even before $1500 \mathrm{BC}-$ these sometimes span almost 1000 years (Garwood $2007,31)$. They evoke the episodic nature of the construction, refurbishment, and use of multi-phased sites, with sometimes very long timespans between activities (ibid., 2007, 34), and their increasing regional diversity towards the middle of the 2nd millennium BC (ibid., 45). They also stress the close relationship between round

TABLE 1: NEOLITHIC AND BRONZE AGE SUB-PERIODS REFERRED TO IN THE TEXT

\begin{tabular}{llcl}
\hline $\begin{array}{l}\text { Broad } \\
\text { sub-period }\end{array}$ & $\begin{array}{c}\text { Specific } \\
\text { sub-period }\end{array}$ & Abbreviation & Dates BC \\
\hline Earlier & Late Neolithic & LN & $2900-2300$ \\
Bronze Age & $\begin{array}{l}\text { Early Bronze Age } \\
\text { Later }\end{array}$ & EBA & $2300-1500$ \\
Middle Bronze Age & MBA & $1500-1150$ \\
Bronze Age & Late Bronze Age & LBA & $1150-800$ \\
\hline
\end{tabular}

barrows and earlier (Neolithic) features - hence even in the earlier Bronze Age round barrows can be seen as accumulations of historical trajectories (ibid., 39-41; Last 2007b). Indeed Garwood (2007, 46), following Brück (2004, 321), suggests that some round barrows were built primarily to create a sense of history rather than for funerary purposes. One key point to take from these analyses is that, in some circumstances, earlier Bronze Age activities at round barrows were intense and intimate to the extent that the people undertaking these practices potentially retained and responded to quite specific memories of previous activities at the same site (situations evoked particularly well in Mizoguchi (1993), Last (1998), and Garrow et al. (2014)). At other times, however, these features almost certainly held much more diffuse historical associations even during their earlier trajectories (see also Barrett 1994, 127-8). Importantly every one of these detailed accounts ends somewhat abruptly at c. $1500 \mathrm{BC}$ (eg, Garwood 2007).

By contrast, studies of the later Bronze Age view round barrows almost exclusively as archaic entities. It is as if at some point in the mid-2nd millennium BC these features slipped seamlessly from the Bronze Age 'present' into its 'past'. We might see this as an example of what Lucas (2005, 54-5; following Moore 1995) argues is a broader archaeological tendency towards 'originary narratives' - those that give primacy to the earliest appearances of certain practices or entities (see also Barrett 1999). In this context later activities at existing archaeological features, and even practices that involve creating new versions of them, are seen to mark processes of decline and are paid little attention. This is true even though, in some cases, the time interval that elapsed between earlier and later Bronze Age activities at monuments was almost certainly quite similar to that which elapsed between episodes of activity within the earlier Bronze Age. This sense of disjuncture between earlier and later Bronze Age accounts of round barrows is arguably reinforced by studies that bridge the mid-2nd millennium BC (eg, Barrett 1994). As Lucas notes $(2005,55)$, focusing on 'transition' is a strategy that is adopted in order to overcome the tendency towards originary narratives, but which often, in fact, reproduces the linear, sequential conceptions of time that these elicit.

Later Bronze Age studies that mention round barrows can be split into two main groups. The first comprises studies that seek primarily to explain broad 


\section{A. Cooper. ROUND BARROWS IN THE LATER BRONZE AGE OF LOWLAND BRITAIN}

shifts in the evidence-base between the Early and Middle Bronze Age - the emergence of archaeologically visible settlement and extensive land boundary systems, shifts in funerary practices (including the development of isolated cremation cemeteries), the substantial rise in metalwork deposits, and so on. The second group includes studies that focus mainly on separate aspects of this novel suite of later Bronze Age practices. In both cases it can be argued that most studies overlook the role of round barrows - these features are separated out from the new material and architectural repertoire historically, spatially, and conceptually.

Studies that seek to explain the Early-Middle Bronze Age transition are united, in some ways contradictorily, in two main respects. On one hand, they are keen to stress continuity in practice alongside major changes in the evidence base in the mid-2nd millennium BC. On the other hand, an explicit agenda of many of these studies is to explain how elaborate Late Neolithic and Early Bronze Age ceremonial practices lost their place amongst later Bronze Age communities with the rise of more intensive farming practices (eg, Barrett 1994, 5). More specifically, Bradley $(2007,201)$ suggests, 'one point is quite clear. In southern Britain the embellishment of barrow cemeteries had reached its limit by the end of the earlier Bronze Age ... these earthworks were no longer an effective way of communicating relationships with the dead' (see also Appleby 2013, 93). Since these studies tend to start with the premise that round barrows were in decline during the later Bronze Age, it is understandable that they invest little effort in interrogating their continuing role.

In his ground breaking history of the period 2900-1200 BC in southern Britain, Barrett (1994) presented practices at round barrows as playing a key role in creating the historical conditions that enabled the creation of a new suite of architectures, practices, and social groupings in the later 2nd millennium. In brief, he argued that the focus on named individuals and the materialisation of lineages at round barrows was an essential part of the processes by which certain groups of people became fixed to and began to invest more concertedly in certain parts of the landscape (for instance by building extensive land boundary systems). Barrett identified a fundamental shift in the role of barrows in the mid-2nd millennium. He suggested that while during the earlier Bronze Age they were a consequence of burial ritual, in the later Bronze Age they became a focus of veneration (ibid., 153).
Meanwhile, in Wessex at least, later Bronze Age settlements and fields were positioned such that round barrows were located at their limits (ibid., 152). Overall the central and active role played by round barrows in the earlier Bronze Age is contrasted with the passive and distant position they occupied later on.

Brück's (2000) persuasive questioning of social and practical aspects of major changes in the evidence base around $1500 \mathrm{BC}$ critically challenged assumptions that these shifts were linked directly to agricultural intensification, sedentism, and increasingly mundane (as opposed to ritual) ways of life. In so doing, however, and in concentrating mainly on the occurrence of 'odd' deposits in domestic contexts (Brück 1999, see Garrow 2012 for a longer term overview of practices involving 'odd' deposits), she contended that during the Middle Bronze Age, 'settlements replaced sites such as henges and barrows as loci for material and ideological investment (Brück 2000, 285 [my emphasis]). Consequently Brück's account of the Early to Middle Bronze Age transition arguably distanced round barrows both practically and temporally.

Employing a more empirically grounded and geographically inclusive approach, Bradley $(2007,184-5)$ emphasised the shift away from round barrows in the later Bronze Age by highlighting the marked decline in barrow building; the waning investment in elaborate burials at round barrows; the emergence of new burial practices (cemeteries of urned cremations); and the rise of a new set of material and funerary associations (between human remains and settlement features and between metal objects and watery places/hoards). Considering Bradley's description of the evidence in detail, however, it is clear that the argument for a move away from round barrows in this period is far from straightforward. Bradley commented that, in some areas, field systems 'refer to' or 'respect' round barrows. As he and others have pointed out, both round barrows and field systems involve substantial communal effort and can be viewed in some ways as being monumental (eg, Jones 2005; Yates 2007; Wickstead 2008, 120; Daniel 2009). Bradley mentioned ways in which later Bronze Age settlement features were both materially and formally linked to round barrows, citing the oft-mentioned refitting sherds from settlement and round barrow contexts at Itford Hill, East Sussex (see also Ellison 1978; Bradley 1981; Brück 2000; Woodward 2000). He noted how round-houses formally resemble round barrows both in terms of their shape and spatial organisation, and 
that human remains were occasionally deposited at land boundaries during this period.

Studies that explore specific aspects of the later Bronze Age in lowland Britain (fields, settlements, etc) tend to convey a stronger sense that round barrows retained some relevance during this period. However, the specific nature of this relevance is not clear and is not pursued in detail. This unformulated sense of significance can be seen to link to three main factors. Some studies were undertaken before the impact of developer-funded research was fully appreciated or have taken place in areas where there has been only very limited detailed excavation in recent times. This makes it difficult to discuss in detail spatial, temporal, or other relationships between different aspects of the later Bronze Age landscape. Others were undertaken in geographical areas in which it is possible that round barrows really did play a minimal role, at least in archaeologically visible activities in the later Bronze Age. Additionally, some analyses show little interest in the potential role of round barrows into the later Bronze Age since this issue lies beyond the main thrust of their argument. The following summary focuses primarily on the extent to which round barrows feature in accounts of later Bronze Age funerary practices and fields. Round barrows are notably absent in Brück's significant corpus of work about later Bronze Age settlement (eg, Brück 1999; 2000; 2001b; 2007). Meanwhile it is widely accepted that metal items were deposited at round barrows and/or in association with human remains only very rarely during this period in lowland Britain (eg, Bradley 2007, 186).

\section{Funerary practices and round barrows}

Woodward's (2000) long-term study of round barrows is one of only a handful of studies that discusses directly the ongoing role of round barrows in later Bronze Age burial practices. The wider avoidance of this topic is almost certainly linked to the fact that, as Bradley (2007, 197) put it, 'mortuary rituals of the Middle Bronze Age pose many problems'. Woodward $(2000,43)$ stressed quite clearly that round barrows continued to operate as significant foci for funerary activity in Middle Bronze Age Wessex. New ones were raised and burial practices at round barrows more broadly were diverse. She noted that, much as in the earlier Bronze Age, groups of cremation deposits (both with and without urns) frequently developed at round barrows during this period. Woodward's earlier work also played a seminal role in generating the widely held understanding that the association between cremation cemeteries and round barrows waned towards the end of the 2nd millennium BC (Ellison 1980).

By contrast, round barrows are barely mentioned in Brück's important body of work focusing initially on Late Bronze Age burial practices (1100-550 BC), and subsequently on settlement practices throughout the later Bronze Age (in which deposits of human fragments feature significantly). Brück's (1995, 264) initial focus on exploring the emergence of a 'new set of relationships with the ancestors' during the later Bronze Age led her to exclude specifically from her analysis funerary activity at round barrows. In defining nine contexts in which human remains occur during this period, only in two cases ('possible burial monuments' and 'unburnt bones at earlier burial monuments' - for both of which there are relatively few examples) were round barrows mentioned explicitly (Brück 1995, 247). It is clear that some of the burials in her category inhumation burials (nonsettlement contexts)' and most in the category 'cremation burials or deposits (non-settlement contexts)' were also associated with round barrows (Brück 1995, appx). Regardless of this detail, since her main interest was in the role of human remains in 'non-mortuary' contexts (Brück 1995, 247), none of the burials at round barrows (c. $20 \%$ of her dataset) was analysed in detail. One problem with Brück's approach is that it precludes the development of a balanced understanding of later Bronze Age burial practices (involving round barrows). It could also be argued that by overlooking practices involving human remains undertaken at round barrows, Brück missed an opportunity to strengthen her broader and highly influential thoughts regarding the mingling of 'ritual' and 'everyday' practice in later Bronze Age life.

In this context, the findings of two impressive recent studies of later Bronze Age burial practices - both unpublished MA theses - are significant. Robinson's (2007) detailed survey of Middle Bronze Age cremation practices in East Anglia suggested that one-third of the 60 known burial sites of this period were located at existing funerary monuments (mostly round barrows). On this basis, she suggested, round barrows were still acknowledged as 'conceptual centres' within newly emerging later Bronze Age landscapes (ibid., 74). Caswell's (2013) much broader synthesis of later Bronze Age cremation practices in Britain involving a dataset of c. 1200 cremation sites and 


\section{A. Cooper. ROUND BARROWS IN THE LATER BRONZE AGE OF LOWLAND BRITAIN}

around 4000 separate burials - raises the importance of considering further the significance of round barrows in funerary practices throughout the later Bronze Age. In contrast to Ellison's (1980) much earlier findings, Caswell suggests that a close affinity between cremation burials and round barrows persists into the Late Bronze Age and contends this relationship becomes even stronger towards the close of the 2nd millennium BC almost half his examples for this period occur in round barrow-related contexts (Caswell 2013, 68).

\section{Fields and round barrows}

In contrast to the situation for funerary analyses, most studies of later Bronze Age fields note that round barrows were an important aspect of later Bronze Age landscapes (eg, Bradley et al. 1994; English 2013; Johnston 2001; 2005; McOmish et al. 2002; Wickstead 2008; Yates 2007). In most cases however, the detailed character of relationships between round barrows and fields is not explored. In many such studies, round barrows sit passively on maps of cropmark fields with little comment. Studies of later Bronze Age fields occasionally mention contexts in which round barrows were a) either avoided or respected by later features (eg, English 2013, 49); b) played a structuring role in the layout of the later landscape (eg, English 2013, 140-2); c) offered a system of landholding that was replaced by fields (Yates 2007, 93) or in which land boundaries are thought to separate zones of settlement and earlier burials. Somewhat nebulous arguments have also been made about the extent to which round barrows symbolised ancestral attachments to land (see Whitley 2002 for a critique of the increasingly generic allusion to ancestors as a means of explaining later prehistoric practices) - a role that is seen to have been taken on subsequently by ageing field systems (English 2013, 13). For instance in explaining the spatial overlap of round barrows and fields in the East Anglian fenland, Yates $(2007,86)$ suggested that agricultural landscapes were probably 'ritualised'. Meanwhile researchers inspired by anthropological studies (eg, Helms 1988) have noted that ancestors often play an important role in understandings of land holding in contemporary ethnographic contexts (eg, Johnston 2001, 102; Wickstead 2008, 112).

Two recent studies of field systems on Dartmoor deserve further consideration regarding their handling of round barrows. In both cases some very important arguments are made. Unfortunately the effectiveness of these arguments is hindered by the paucity of recent excavations, meaning that understandings of the chronology of the evidence under discussion are vague.

Importantly, Johnston $(2005,13)$ argued that longlasting (not archaic) structures - round barrows and round-houses, both of which are typically earlier than field systems in this area - played a vital role in the emergence of new understandings of place and in the production of certain kinds of identities in the later Bronze Age on Dartmoor. He also viewed their roles in this respect as being sequential: round-houses took over a position that was occupied previously by round barrows. Consequently, he suggested, round-houses came to occupy an increasingly central place in people's lives, where they shaped the ways in which people developed enduring attachments to particular tracts of land. He highlighted several instances in which round-houses were actively built into land boundaries and were referred to directly in the layout of fields. Meanwhile round barrows were increasingly located at the limits of territories, where they were involved in negotiations regarding access to resources and social status. Ultimately Johnston viewed round barrows as occupying a separate temporal and spatial zone to Middle Bronze Age fields. However, he did at least clearly articulate their ongoing role within the later landscape.

By placing relationships between aspects of the archaeological record at the heart of her account, Wickstead (2008) necessarily examined the character of associations that were made between round barrows, land boundaries, and society on Dartmoor. She rightly challenged both Barrett's (1994) contention that round barrows played an historical role in longerterm processes of territorialisation, and Johnston's suggestion (above) that they operated as an earlier form of territorial marker (Wickstead 2008, 115). Rather, she suggested, it is important to embrace the complexity and long-term variability of Dartmoor's Bronze Age archaeology. There is no clear transition from an earlier Bronze Age emphasis on deposits of individual burials and metalwork in round barrows to a later Bronze Age emphasis on deposits of human fragments and metalwork in other contexts in this region (Wickstead 2008, 119-20). She argues that there was a 'spreading out' of activities previously undertaken at round barrows/cairns into a much wider range of contexts in the later Bronze Age (Wickstead 2008, 125; following Quinnell \& Watts 
2002). Wickstead's account still gives a sense that overall, meaning somehow seeped out from round barrows over the later 2nd millennium BC. However her arguments are important here since she at least attempts to question directly how round barrows related to other aspects of the later Bronze Age landscape.

To summarise, my aim is certainly not to deny that substantial changes took place in the role of round barrows over the later 2nd millennium BC. Rather, it is to suggest that accounts that have focused on the later Bronze Age demise of round barrows have failed to scrutinise in detail what role they actually played. As Barrett $(1994,111)$ importantly pointed out, it is the operation of a 'complex lattice of social trajectories' that we need to evaluate. In this context, he suggested, we need to ask 'what was transformed and what was beld in place in the social practices of the mid to late 2nd millennium?' (ibid., 111 [my emphasis]). I hope to have shown how existing accounts of this period have focused very much on what was transformed at the expense of asking what was held in place, and indeed how these aspects of life were held in place alongside broader changes.

The remainder of this study explores the extent to which one particular element of Early Bronze Age landscapes - round barrows - was held in place in the later Bronze Age. The approach taken draws at a broad level on Olivier's $(2001 ; 2011)$ concept of multitemporality - the idea that at all times peoples' lives comprise accumulations of matter with different origins and of varying durability (see also Ingold 1993). The emphasis placed upon characterising relationships between later Bronze Age activities and round barrows responds to a wider movement within prehistoric landscape studies which recognises that archaeological entities (social identities, monuments, artefact types, etc) are produced through their associations with other phenomena rather than being static or self-evident (eg, Giles 2012, 33-8). More specifically, the analysis also builds on the interpretations developed by Johnston (2005) and Wickstead (2008) discussed above.

\section{LATER BRONZE AGE BARROW RELATIONSHIPS IN THE EAST OF ENGLAND}

The following account examines systematically the character of activity at round barrows in the later Bronze Age in the east of England. ${ }^{3}$ The case study area comprises $4650 \mathrm{~km}^{2}$ spanning the limestone and boulder clay landscapes of Northamptonshire to the mixed heath of the Suffolk and Norfolk Breckland (Fig. 1). It is bisected from north to south by two major rivers - the Nene and the Great Ouse - that provided a distinct focus for Bronze Age activity. Throughout our period of interest the central part of this area would have been dominated by a dynamic coastal wetland - the East Anglian fenland - punctuated by islands of higher ground (Waller 1994).

\section{Method}

The core analytical dataset comprises evidence for the period from $1500-800 \mathrm{BC}$ relating to 87 'excavated' round barrows that can be grouped into 40 'sites' (single barrows or barrow groups) ${ }^{4}$ and were logged within 53 digital records drawn from local Historic Environment Records (HERs), Historic England's (HE's) National Record for the Historic Environment (NRHE) and Excavation Index (EI), Online Access to the Index of Archaeological Investigations (OASIS), and the British and Irish Archaeological Bibliography (BIAB). ${ }^{5}$ These records formed a starting point for the analysis and were selected from a total pool of 173 digital records relating to excavated round barrows within the study area. Priority was given to examining excavated round barrows with easily accessible reports. ${ }^{6}$ Beyond this, the aim was to achieve broad spatial coverage across the study area (balancing out the higher density of excavated sites in Cambridgeshire) and to focus primarily on sites that were recovered during extensive, high-quality excavations mostly following the rise of developer-funded archaeology in the late 1980 s.

For each excavated round barrow site, relevant reports were examined in detail. All activity relating to the period $1500-800 \mathrm{BC}$ that was located within $50 \mathrm{~m}$ of an existing round barrow, and round barrows that potentially originated in this period, were logged in a database. Within extensive excavated landscapes, all later Bronze Age practices that are traditionally associated with Early Bronze Age round barrows (eg, funerary, ritual, and monument-building activities) were recorded in the database whether or not they were located within $50 \mathrm{~m}$ of a round barrow. This allowed for an assessment to be made of the ongoing trajectory of these practices. Key excavated sites mentioned in the text are listed in Table 2 and highlighted in Figure 1. In the following analysis the findings under discussion relate to this core dataset unless otherwise stated. 


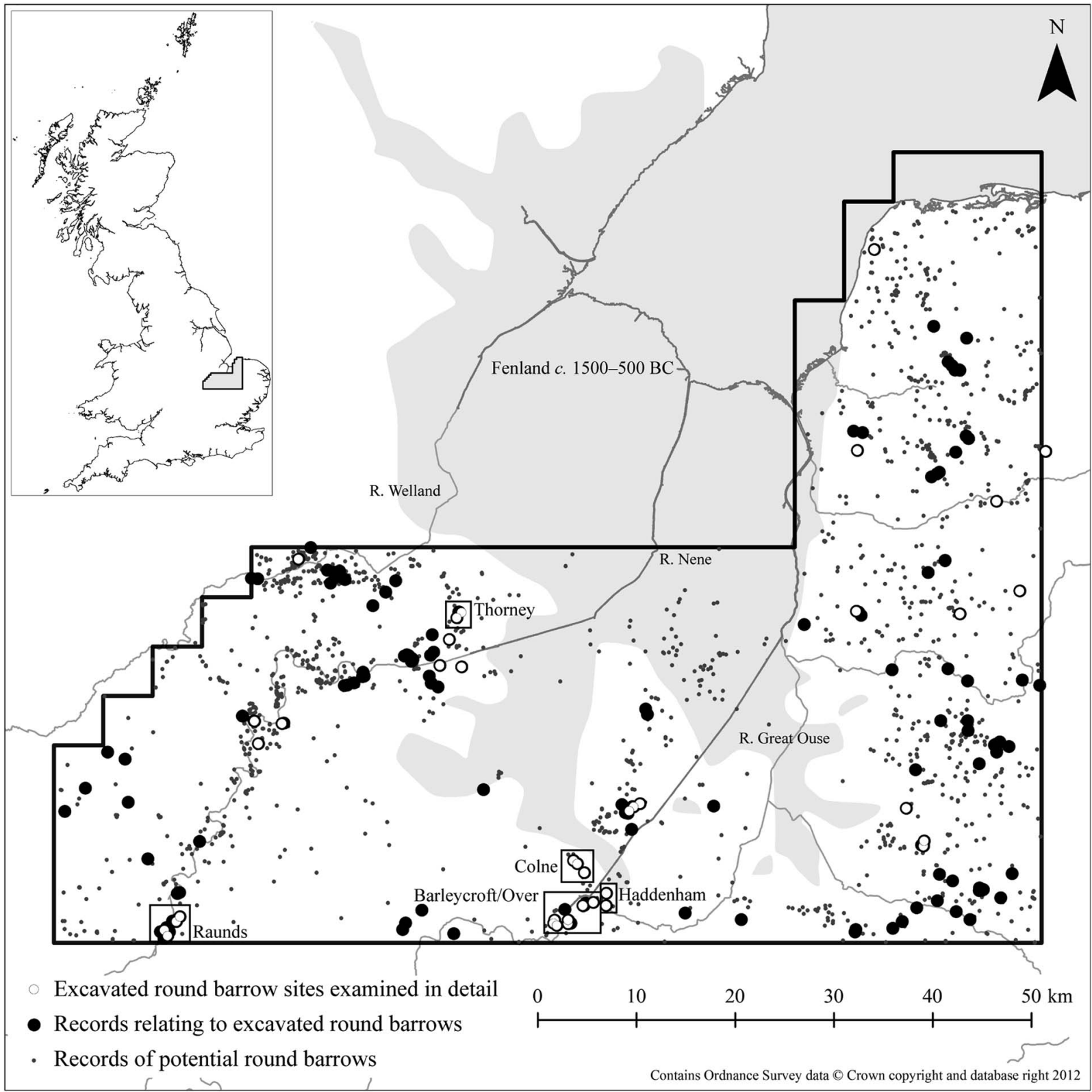

Fig. 1.

East of England case study area showing round barrows and key excavated landscapes mentioned in the text

The main traits recorded in the database are summarised in Appendix S2. In order to contextualise the findings from this core dataset, all 173 digital records were also 'enhanced' within the EngLaID project database (see Cooper \& Green 2016). This involved creating separate 'monument types' for later Bronze Age activities that were mentioned in the site descriptions of digital records but were not otherwise represented either as analysable 'monument types' or in separate records. ${ }^{7}$

\section{RESULTS}

\section{Broad summary}

Later Bronze Age evidence was recovered at 28 (72\%) of the 40 round barrow sites examined in detail. 
TABLE 2: KEY EXCAVATED ROUND BARROW SITES MENTIONED IN THE TEXT

\begin{tabular}{lclll}
\hline Site name & $\begin{array}{c}\text { No. round } \\
\text { barrows }\end{array}$ & Excavated landscape & County & Reference \\
\hline Snow's Farm, Haddenham & 1 & Haddenham & Cambridgeshire & Evans \& Hodder 2006 \\
Barleycroft Paddocks & 1 & Barleycroft/Over & Cambridgeshire & Evans \& Pollard 1995 \\
Butcher's Rise & 2 & Barleycroft/Over & Cambridgeshire & Evans \& Knight 1998 \\
Southern Field, Barleycroft & 1 & Barleycroft/Over & Cambridgeshire & Evans \& Knight 2000; 2001 \\
Over Low Grounds & 5 & Barleycroft/Over & Cambridgeshire & Evans et al. 2014; forthcoming \\
Camp Ground & 1 & Colne & Cambridgeshire & Evans et al. 2013 \\
Rhee Lakeside (South) & 1 & Colne & Cambridgeshire & Evans et al. 2013 \\
Pode Hole Farm & 5 & Thorney & Peterborough & Daniel 2009; Ellis et al. 2001 \\
Bar Pasture Farm & 2 & Thorney & Peterborough & Richmond \& Coates 2010 \\
Brigg's Farm & 1 & & Peterborough & Pickstone \& Mortimer 2011 \\
Irthlingborough & 4 & Raunds & Northamptonshire & Healy \& Harding 2007 \\
Stanwick & 3 & Raunds & Northamptonshire & Healy \& Harding 2007 \\
West Cotton & 2 & Raunds & Northamptonshire & Healy \& Harding 2007 \\
Tansor Crossroads & 1 & & Northamptonshire & Chapman 1997 \\
Tallington & 4 & & Lincolnshire & Fennell 1961; Simpson 1976 \\
\hline
\end{tabular}

The evidence included one isolated round barrow site - at Block Fen - that was potentially constructed in the later Bronze Age (Hunn 1992), and 64 separate incidences of later Bronze Age activity (within $50 \mathrm{~m}$ of) at the remaining 27 round barrow sites. Significantly, $40(63 \%)$ of these incidences were assigned a specifically Middle Bronze Age date, while only nine (14\%) were almost certainly of Late Bronze Age origin. The remaining activities were less precisely dated, having an overall date span of 1800-400 BC (only 14 incidences of activity were given a date span that overlapped with, but also extended beyond, the period $1500-800 \mathrm{BC})$. The following account therefore focuses mainly on evidence for Middle Bronze Age activity at round barrows. In $90 \%$ of cases the association between the later Bronze Age activity and round barrow sites was thought to be potentially meaningful (rather than incidental). Put slightly differently, well over half $(67 \%)$ of the excavated round barrow sites examined in detail appeared to be actively linked with later (mostly Middle) Bronze Age practices in an archaeologically visible way.

Figure 2 and Table 3 give an overview of the kinds of later Bronze Age activity undertaken at existing round barrow sites in the study area according to 'specific evidence types' (Table 3), 'broad monument classes' (Fig. 2a), and 'practice-based classes' (Fig. 2b). ${ }^{8}$ The latter were devised specifically for this study in order to offer a more nuanced and interpretatively relevant version of the EngLaID and HE thesaurus classes (see Appendix S3). Key points to take from these summaries are that funerary and ritual
TABLE 3: INCIDENCES OF LATER BRONZE AGE ACTIVITY AT EXCAVATED EARLY BRONZE AGE ROUND BARROW SITES

\begin{tabular}{lc}
\hline HE-thesaurus derived monument type & No. examples \\
\hline Unspecified field system & 15 \\
Unenclosed settlement & 8 \\
Cremation cemetery & 7 \\
Unspecified settlement & 6 \\
Development of earlier round barrow & 6 \\
Trackway/drove road & 6 \\
Cremation burial & 5 \\
In-situ flintworking & 2 \\
Pit alignment & 2 \\
Ring-ditch & 2 \\
Enclosure & 1 \\
Finds & 1 \\
Inhumation burial & 1 \\
Post alignment & 1 \\
Unspecified burial & 1 \\
\hline
\end{tabular}

activities form the main broad class of evidence encountered at round barrow sites. These mainly comprise cremation groups, single cremations, the enhancement of existing monuments, or the creation of new versions. Field systems and settlements were also commonly located nearby.

It is also interesting to note the broad spatial patterning of round barrows that attracted later Bronze Age activity in the study area (Fig. 3). Such activity was identified at most round barrows in the Great Ouse Valley along with many examples in the Nene Valley. This was not necessarily the case, however, for round barrows in the eastern part of the study area. 

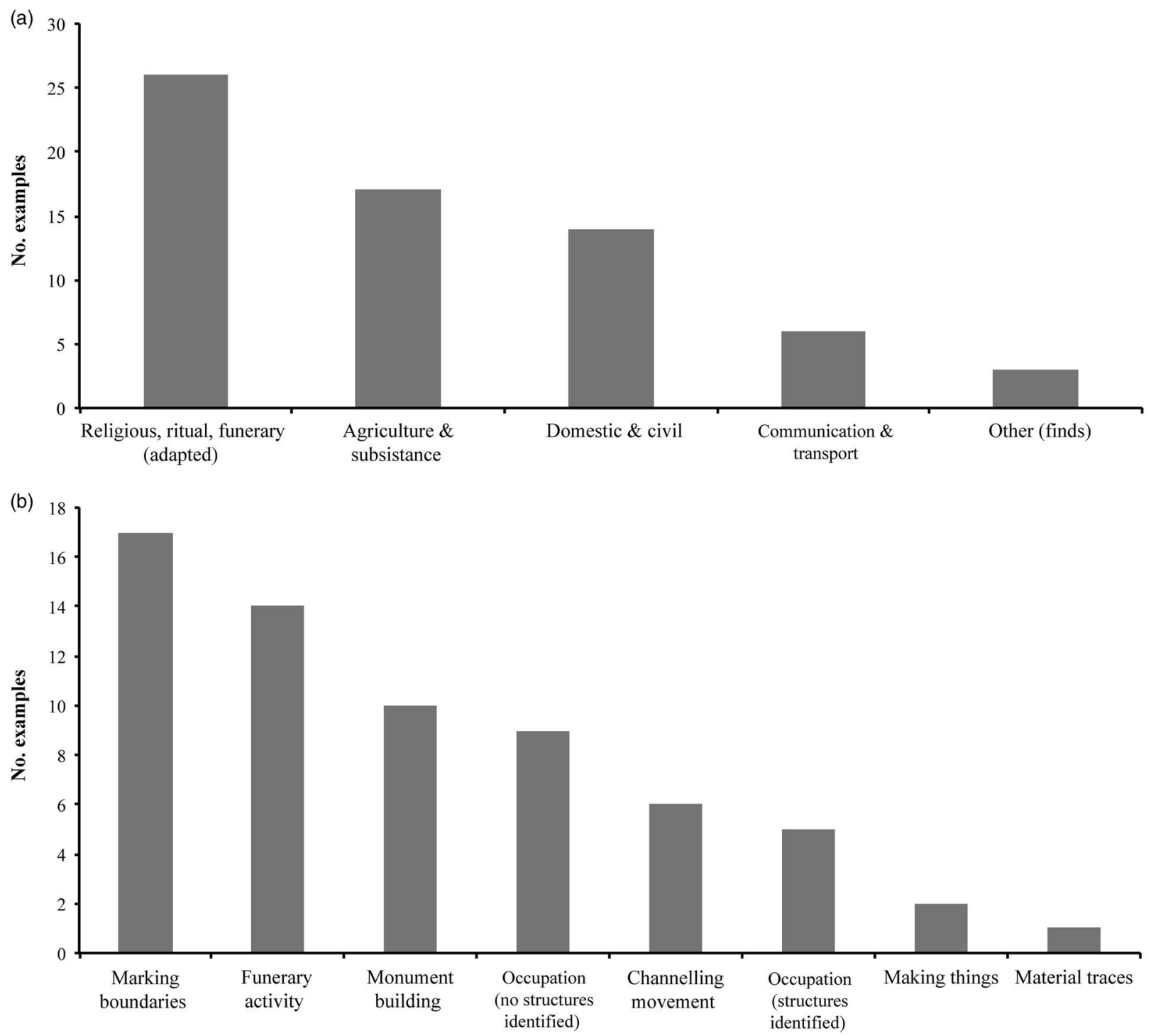

Fig. 2.

a) Later Bronze Age activity at excavated round barrow sites (broad HE thesaurus classes); b) Later Bronze Age activity at excavated round barrow sites (broad practice-based classes)

Funerary practices and round barrows

Later Bronze Age funerary activity was recorded at 13 round barrow sites. Evidence for the Middle Bronze Age includes six cremation cemeteries, three isolated single cremation burials/pairs, one funerary pyre, and one site with dispersed cremations and an inhumation potentially of the same phase. Evidence for the Late Bronze Age comprises one cremation cemetery, one isolated cremation, and one potential incidence of fragmentary human remains. Interestingly, this temporal patterning contrasts with the findings of Caswell's $(2013,68)$ recent study, which indicated a nationwide trend towards locating cremation burials at round barrows at the very end of the Bronze Age. Beyond the cremation cemeteries (which obviously accrued over a period of time), only in two cases were separate later Bronze Age burial episodes recorded at the same site. At Snow's Farm, Haddenham, a Middle Bronze Age funerary pyre was identified at the northern edge of the round barrow, while a cremation cemetery to the 


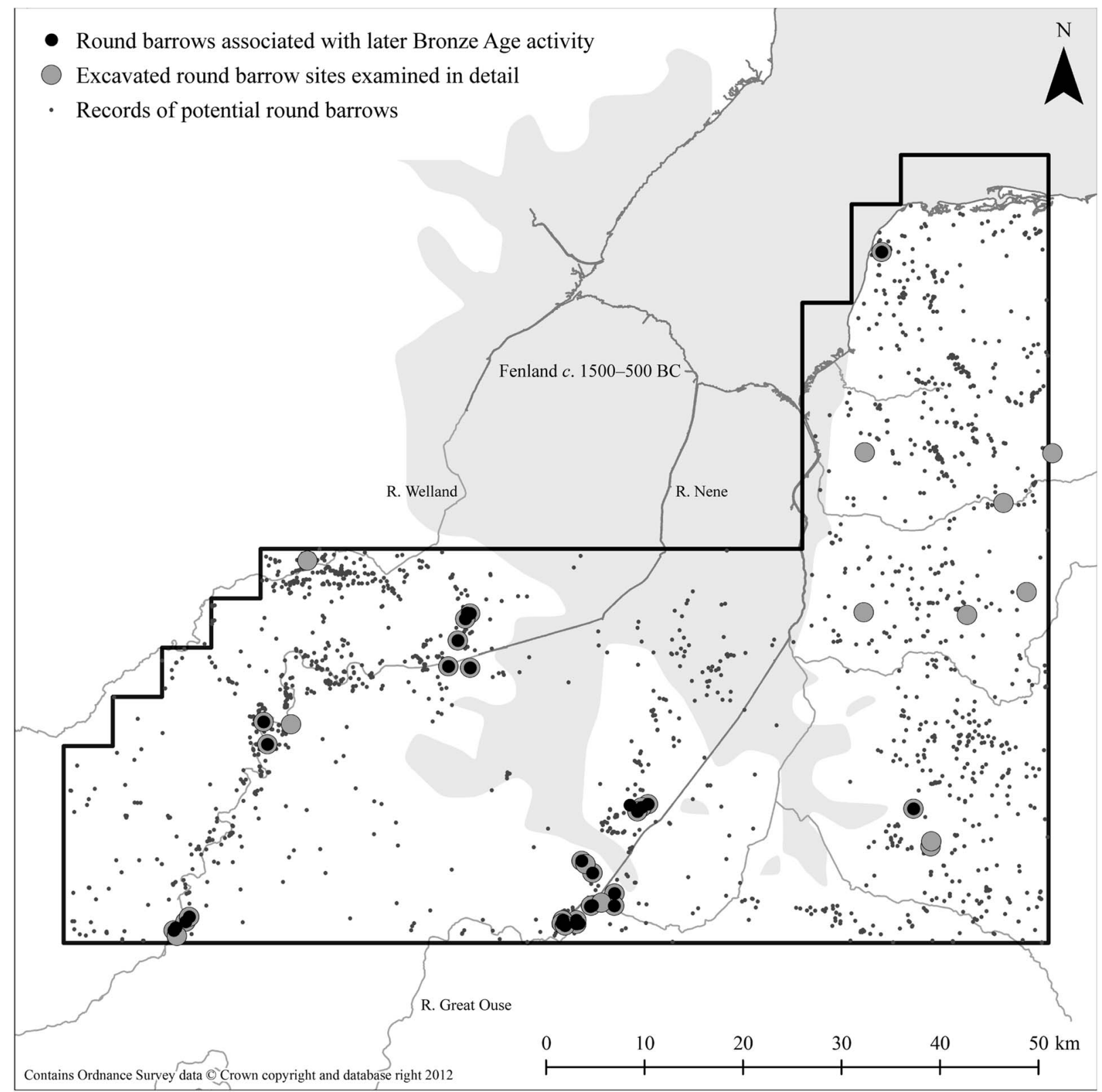

Fig. 3.

Excavated round barrow sites associated with later Bronze Age activity

south was dated to span the early 1st millennium BC. The diverse interments at Over Low Grounds are discussed below.

The broad spatial patterning of this funerary evidence is striking (Fig. 4). Although overall, incidences of later Bronze Age cremations at round barrows are fairly widely distributed, all but one of the cremation cemeteries at sites examined in detail occurred in the Great Ouse valley. Later Bronze Age funerary evidence from the region more broadly (eg, French 1994; Robinson 2007; Hutton 2008; Richard Mortimer pers. comm.) suggests that isolated cremations and cremation pairs were located at round barrows across East Anglia and into Lincolnshire. However sizeable cremation 


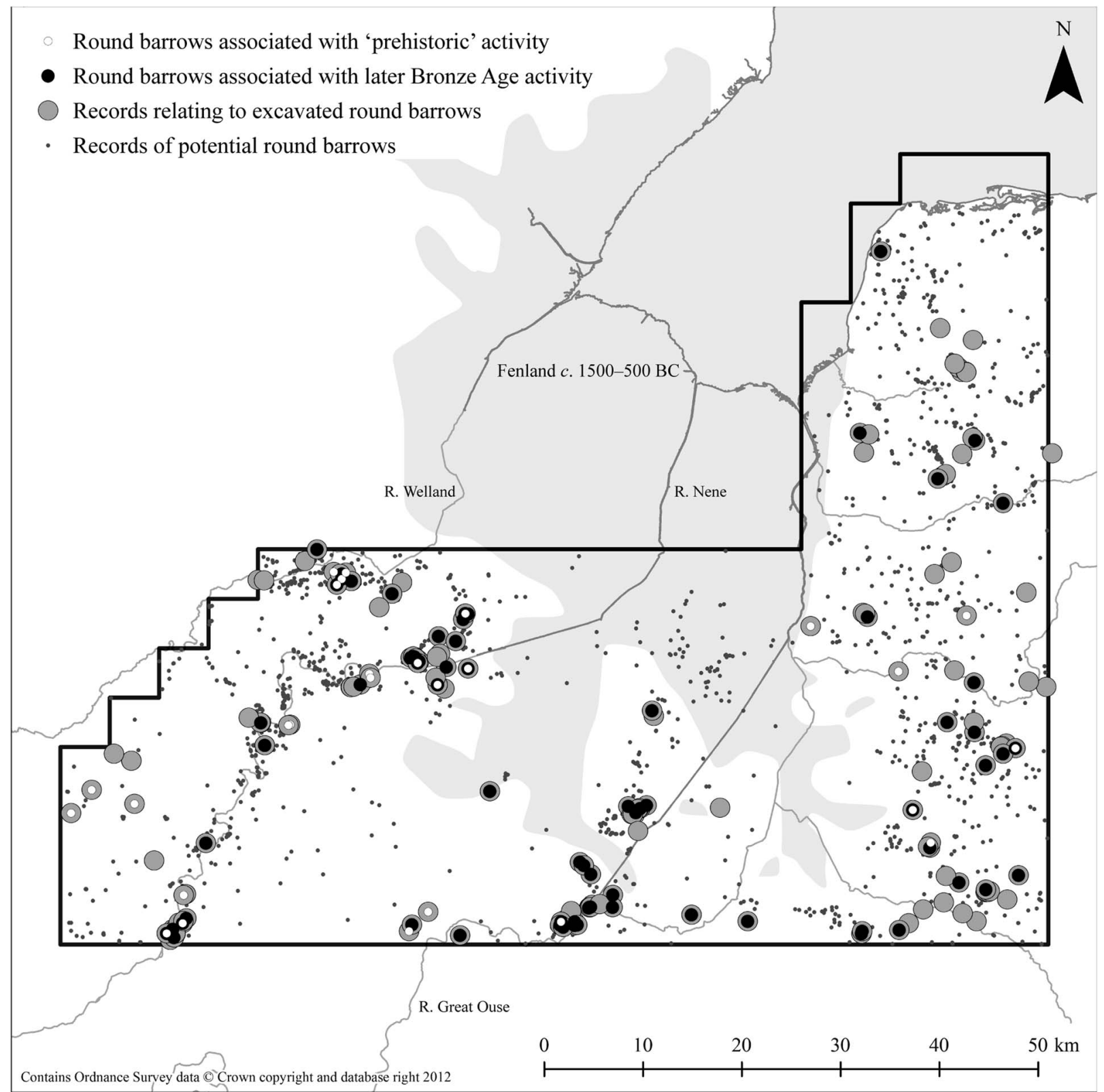

Fig. 3.

Continued

groupings - comprising more than ten burials - such as those at round barrows along the lower Great Ouse valley are relatively rare (see Evans \& Appleby 2008 for the only other example within the study area). This raises the possibility that a particular emphasis on interring cremations relatively formally at existing round barrows emerged amongst communities along the river Great Ouse during the later Bronze Age.
All but one of the funerary episodes identified in this study were associated directly with the round barrow cremations were either cut into the mound or the partly in-filled ring-ditch, or were positioned immediately outside the ring-ditch. The precise choreography of cremation cemeteries varied - some were broadly linear (eg, Rhee Lakeside (South) and Snow's Farm, Haddenham), while others followed the curve of the 


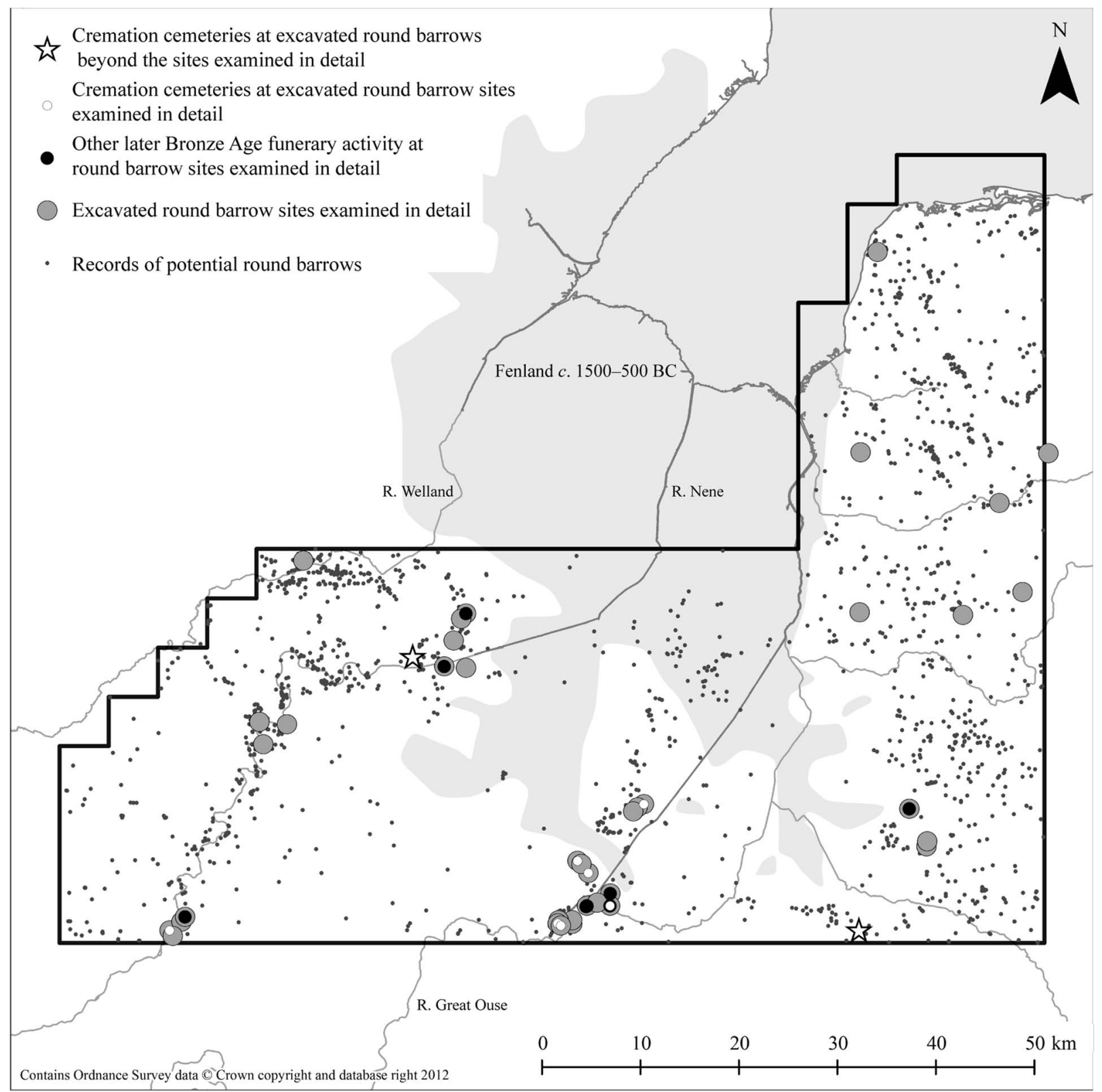

Fig. 4.

Later Bronze Age funerary activity at excavated round barrow sites

ring-ditch (eg, Camp Ground). In all of the Great Ouse valley cemeteries, cremation pits intercut and clusters were apparent within the overall burial group. At Butcher's Rise it was even possible to gain a sense of the sequence of interments - the earliest cremations were located closest to the centre of the ring-ditch with later ones being added concentrically outside of these
(Evans \& Knight 1998, 27-9). ${ }^{9}$ More broadly, there is clear patterning regarding the positioning of later Bronze Age cremations where they intersected directly with round barrows. In all these cases burials were located towards the outer edge of the monument. Cremation cemeteries were typically situated on the southern flank of the barrow, usually slightly to the 


\section{A. Cooper. ROUND BARROWS IN THE LATER BRONZE AGE OF LOWLAND BRITAIN}

south-west. While the positioning of single and paired cremations was slightly more diverse, most were also to the south.

Overall, it appears that there were widely held understandings about how to inter cremated human remains at round barrows in the later Bronze Age (see also Woodward 2000, 43; Robinson 2007). Within this broad patterning, however, commonalities in burial histories (the development of cremation cemeteries) and in practical emphases (intercutting interments, positioning relative to barrow features) appear to have emerged along certain valley systems.

It is worth raising two further points in relation to this evidence set. All of the round barrow sites that produced evidence for later Bronze Age funerary activity also produced Early Bronze Age (and/or occasionally Neolithic) burials. In all but one case the later Bronze Age cremations appear to represent an entirely separate episode of activity - they were spatially distinct from the earlier burials or they produced significantly later radiocarbon dates. Additionally, in at least four cases, at Camp Ground, Rhee Lakeside (South), Snow's Farm and Butcher's Rise, later Bronze Age funerary activity was more intensive than that for the Early Bronze Age the funerary role of these barrows flourished rather than faded in the later Bronze Age.

\section{Monument building}

Evidence for later Bronze Age monument building at (and also potentially beyond) existing round barrows is relatively widespread. Unfortunately this evidence is often poorly dated or has yet to be published in detail (a precise date within the later Bronze Age could not be assigned to any of the examples discussed here). However it is clear that during this period communities did add to older barrows, made new (smaller) versions, and also created novel monuments that referenced round barrows; in most cases the work undertaken was relatively small-scale.

Round barrows at six sites were embellished or redefined in the later Bronze Age. Again most of these examples were in the Great Ouse valley. This typically involved recutting the ring-ditch of an existing round barrow or adding a new ring-ditch concentrically. At Snow's Farm a post ring was added to the existing monument. At Tansor Crossroads a causeway was built across the ring-ditch. Meanwhile the pond of one of the barrows from the Over Low Grounds cemetery was recut (Evans et al. forthcoming). In most cases it appears that these developments occurred as part of a wider set of later Bronze Age activities - roughly contemporary burials or settlement features were also located nearby.

Evidence for the creation of new monuments at round barrows in the later Bronze Age is particularly unclear. Small (under $10 \mathrm{~m}$ in diameter) ring-ditches were identified just to the south of earlier (larger) examples at Bar Pasture Farm and West Cotton. In both cases these were essentially undated. However very similar and occasionally more securely dated examples have been identified both locally and more broadly (eg, at Salthouse Heath, Norfolk (Wake 1942); Aldham Mill Hill, Suffolk (Martin et al. 2001); St Osyth, Essex (Germany 2007), Langtoft Quarry, Lincolnshire (Hutton 2008), and Fengate (Evans 2009)). In two instances - both in the Barleycroft/Over landscape - new forms of later Bronze Age monument were identified, at least one of which related directly to a round barrow cemetery. The Middle Bronze Age 'ringwork' (c. $100 \mathrm{~m}$ in diameter) at Over Site 9 is positioned immediately to the north of a large barrow cemetery and encircles a richly furnished pond barrow together with substantial later Bronze Age settlement activity. ${ }^{10}$ The Late Bronze Age post alignments at Barleycroft were located some distance from the nearest round barrow (Evans \& Knight 2000; 2001, 89). Even so, these massive communal works are thought to have cited valued aspects of the local topography including round barrows: a gap in one of the alignments provides a direct line of sight between two barrow cemeteries either side of the river Great Ouse (Evans 2009, 55). This could imply that, even in experimenting with novel monumental forms, later Bronze Age communities in this particular (arguably somewhat round barrow-centric) landscape did so with active reference to earlier ones.

\section{Fields and round barrows}

Later Bronze Age land boundaries were located at 15 of the round barrow sites. In six cases the fields were associated with trackways or drove roads. All but three of these features/systems were assigned specifically to the Middle Bronze Age (although it is certainly possible that they accrued over considerable time periods eg, Evans 2009, 64). These sites were distributed widely over much of the study area. However, no Bronze Age field systems were identified at round barrows towards the east (in fact very few prehistoric field systems have been excavated extensively in this 
area - see Connor \& Mortimer forthcoming; Gibson 2004; Gilmour et al. 2014 for notable exceptions). Unsurprisingly, the precise form and development of land boundary systems at round barrows varied overall. Significantly, however, the ways in which land boundaries connected directly with existing round barrows varied more substantially between broad landscape areas than within them.

Excavation reports observe widely that existing round barrows were considered in the overall design of Middle Bronze Age land boundary systems. In the Barleycroft/Over landscape, Evans and Knight (2000, 97; 2001, 92-3) suggest that land boundaries to the west of the river Great Ouse were organised radially around a pair of existing ring-ditches situated on a raised knoll and that round barrows operated as 'nodal points' more broadly in this system. Meanwhile to the east of the river, land boundaries appear to 'accommodate' or 'frame' the existing monuments (Evans \& Knight 2000, 84; Evans 2009, 55; Evans et al. forthcoming). At Pode Hole Farm, the earliest 'axial' land boundary runs directly through the middle of a broadly linear group of round barrows, reinforcing both their alignment and that of the nearby fen-edge (Daniel 2009, 22-5). In three further instances it was noted that the character of fields (in terms of their form and orientation) differed on either side of a barrow (at Bar Pasture Farm, Brigg's Farm, and Stanwick). In some of these cases it is possible that the enclosure systems located on either side of the barrow were built by different groups of people and/or at different times. In others, however, it appears that land boundaries were used in conjunction with round barrows to reinforce separations between activity zones (eg, between a tightly defined settlement area on higher ground and more loosely delimited occupation close to the fen-edge at Brigg's Farm). These observations add important subtlety to existing broad arguments regarding the inter-relationship of barrows and fields, both in the east of England (eg, Bradley 2007, 188; Yates 2007, 86) and more broadly.

More interesting interpretatively are the specific ways in which some land boundaries were physically linked to round barrows (Fig. 5). In some landscape areas, land boundaries ran up to barrows and terminated at or alongside them (in the Barleycroft/Over landscape). In others, field ditches cut into the edge of barrows and access to the monument was built into the field system (at Rhee Lakeside (South) and in the Thorney landscape). Occasionally land boundaries were cut directly across existing round barrows (eg, in the Raunds landscape).

In considering this particular set of associations it is important to highlight that while in some landscapes (at Barleycroft/Over), the fabric of the existing round barrow was never directly infringed upon, in others (at Thorney and at Raunds), the body of the monument was often actively disturbed. In this case, the people involved in cutting the ditches would necessarily have risked encountering existing funerary deposits - a possibility that they would almost certainly have been aware of. Such an encounter may even have taken place at Pode Hole Farm, where an adult human femur was recovered from a field boundary terminal that cut into one of the ring-ditches (Ring-ditch 1, Brayne in Daniel 2009, 146). The use of value-laden words like 'respected' or conversely 'disregarded' or 'effaced', to describe such encounters is, to my mind, slightly unhelpful. Engaging physically with a round barrow by cutting a land boundary into or across it could arguably have produced an even stronger sense of connection with an existing monument than stopping a boundary before it. What is perhaps notable is that in every case, the outcome was enduring. Understandings of how fields related to round barrows were actively inscribed into the landscape - they were marked materially in a way that left them open for interpretation beyond the group who were initially involved in defining them (Connerton 1989, 73; Rowlands 1993, 142).

Overall, the evidence outlined above suggests that existing round barrows mattered enough to later Bronze Age people that they had to be dealt with actively when field systems were developed in their vicinity. Intriguingly, it also appears that a specific set of grammars emerged regarding how barrows should be linked into land boundary systems. More importantly, there is a sense of coherence within broad landscape areas about the way in which these relationships were enacted. It is certainly possible that choosing how to weave round barrows into a newly enclosed landscape was one way in which later Bronze Age communities within the study area defined themselves. The common observation that the location of barrows corresponds with changes in land boundary systems is also compelling. Along with Wickstead (2008, 114-15), I would argue that this does not necessarily imply that land boundaries were cementing earlier systems of landscape organisation in which enduring features played a key role. Rather, it seems 


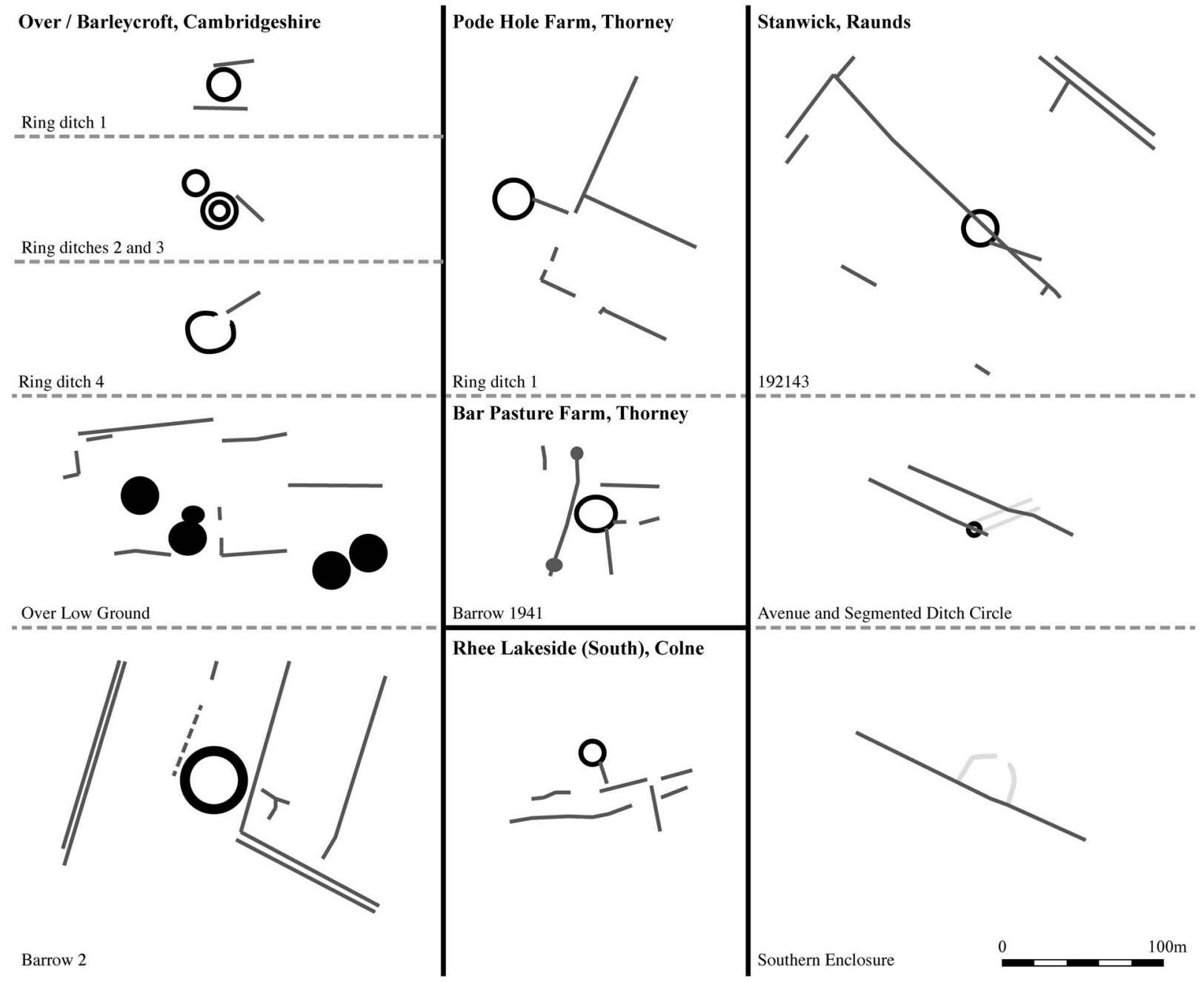

Fig. 5 .

Schematic configurations of later Bronze Age land boundaries and round barrows (after Daniel 2009; Evans et al. forthcoming; Evans et al. 2013; Harding \& Healy 2007; Richmond \& Coates 2010)

equally likely - particularly within the dispersed barrow landscapes of the east of England (Fleming 1971, 141) - that existing features were simply seen to be helpful in the process of marking out areas that were meaningful in the later Bronze Age.

\section{Settlement activity and round barrows}

Later Bronze Age settlement and other activities (in situ flintworking, and a potential metalwork deposit) were encountered at 15 round barrow sites (Fig. 6). This incidence is perhaps surprisingly high given that associations between barrows and later
Bronze Age settlement have rarely been discussed, beyond obvious examples in Wessex (see above). This evidence also stands out for a number of other reasons. First, occupation evidence at round barrows spans the Middle and Late Bronze Age - six sites were dated specifically to the Late Bronze Age and a further ten have been assigned dates that extend into the $1 \mathrm{st}$ millennium BC. Secondly, the ways in which settlement activity was connected to nearby round barrows are somewhat ambiguous. It is often difficult to assess whether or not the association was meaningful in any way. Additionally, it is sometimes hard to evaluate whether the activity concerned was straightforwardly 


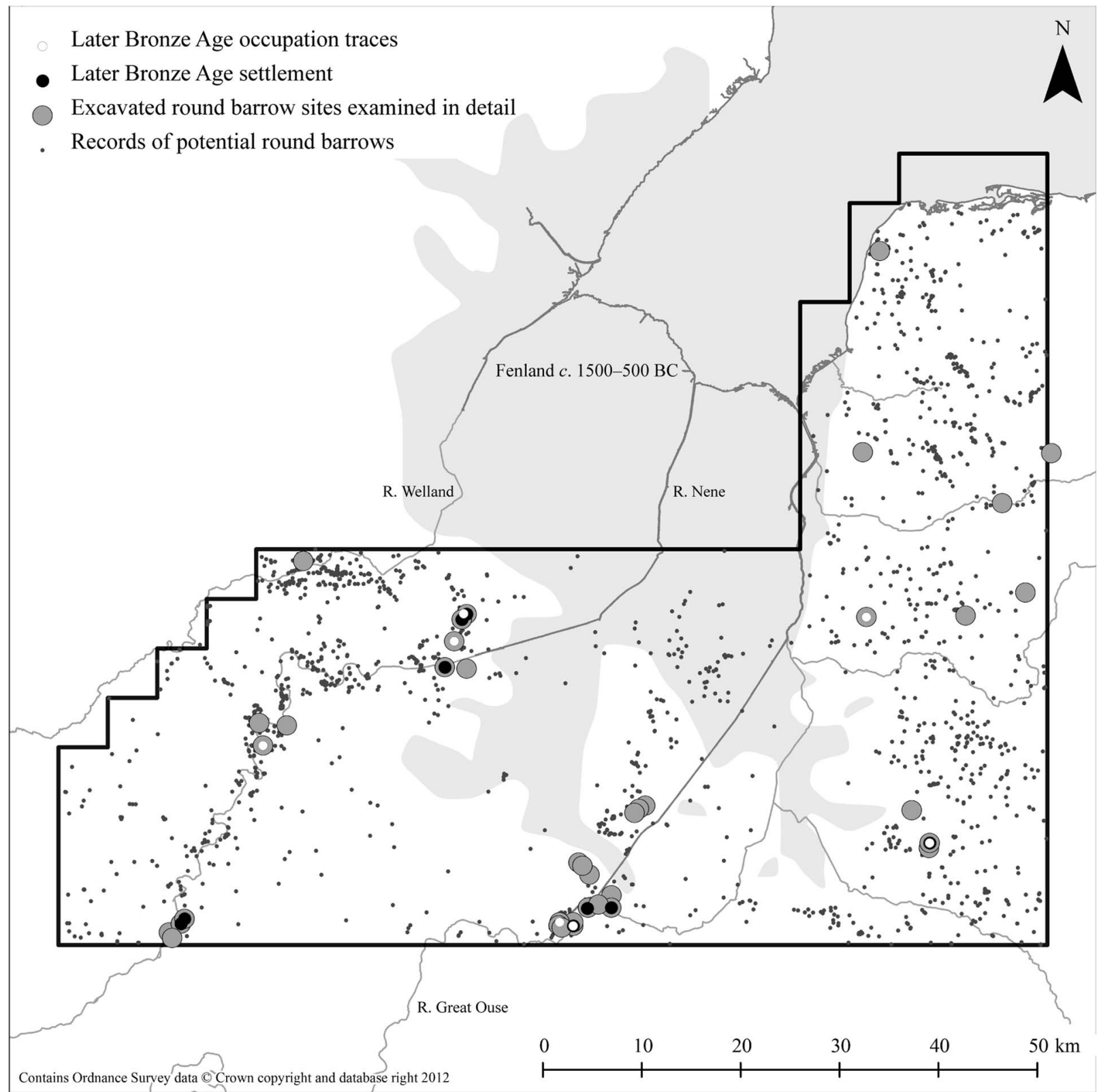

Fig. 6.

Later Bronze Age 'settlement' activity at excavated round barrow sites. Later Bronze Age 'settlement' (sites with evidence for substantial domestic activity, usually including structural features) is distinguished from later Bronze Age 'occupation traces' (sites comprising seemingly isolated or ephemeral settlement features - pits, post-holes etc)

settlement-related rather than representing some form of specifically barrow-related 'ritual' activity.

At six of these sites, later Bronze Age settlementrelated features (pits, post-holes, water-holes) were cut into or located near a round barrow, or potentially settlement-related debris was deposited in the upper fills of a ring-ditch and in nearby pits and boundary ditches. On several occasions, the material within these features was heavily burnt. At Barleycroft Paddocks, more substantial Middle Bronze Age settlement evidence was 


\section{A. Cooper. ROUND BARROWS IN THE LATER BRONZE AGE OF LOWLAND BRITAIN}

located in excavated trenches $c .50 \mathrm{~m}$ to the north of the ring-ditch. Elsewhere, however, this activity appears to have taken place in relative isolation. Overall, these traces could represent a combination of practices including ephemeral occupation at round barrows and ritual activity that involved creating pits and post-hole structures and depositing burnt material (charcoal, pottery, stones, unidentifiable bone fragments, etc).

At a further eight round barrow sites, more substantial later Bronze Age settlement remains were recovered - often these were quite extensive and included structural evidence. In every case, the settlement core was some distance away $(50-150 \mathrm{~m})$ from the barrow(s) - only occasional pits and post-holes containing settlement debris were situated more closely. Hence, it appears that the relationship between intensive later Bronze Age settlement activity and round barrows was relatively remote in most cases.

In situ later Bronze Age flintworking was identified at two round barrows from the cemetery at Irthlingborough (Fig. 7). At Barrow 1 - a monument with a remarkable Early Bronze Age history and at which a small group of Middle Bronze Age cremations was also deposited (Harding \& Healy 2007, 153-64) - two in situ flint scatters were identified on the flanks of the mound, each probably representing a single knapping episode (Bjarke Ballin in Harding \& Healy 2007, 187). At Barrow 3 a similar concentration was identified immediately to the north-east of the round barrow. The raw material that makes up c. $10 \%$ of both scatters derives from the Boulder Clay plateaus beyond this valley (ibid.). This implies that, in contrast to the supposedly ' $a d$ boc' flintworking practices that are thought to characterise this period (Young \& Humphrey 1999; Humphrey 2004, 214), these scatters represent planned knapping episodes in settings that are some distance from known contemporary settlement activity. A large quantity of flintworking debris was also recovered from one quadrant of the ring-ditch and from the buried soil above this at Butcher's Rise, while similar evidence was recorded at Orton Longueville Peterborough (Harding \& Healy 2007, 190). A wider association between round barrows and later Bronze Age flint knapping seems likely.

Only on one occasion was later Bronze Age metalwork encountered at a round barrow. A spearhead tip was recovered from the ploughsoil above the round barrow at Snow's Farm, Haddenham. It is certainly possible that this represents an act of 'ritual' deposition at a round barrow that was also a focus for two main episodes of funerary activity during this period (see above).

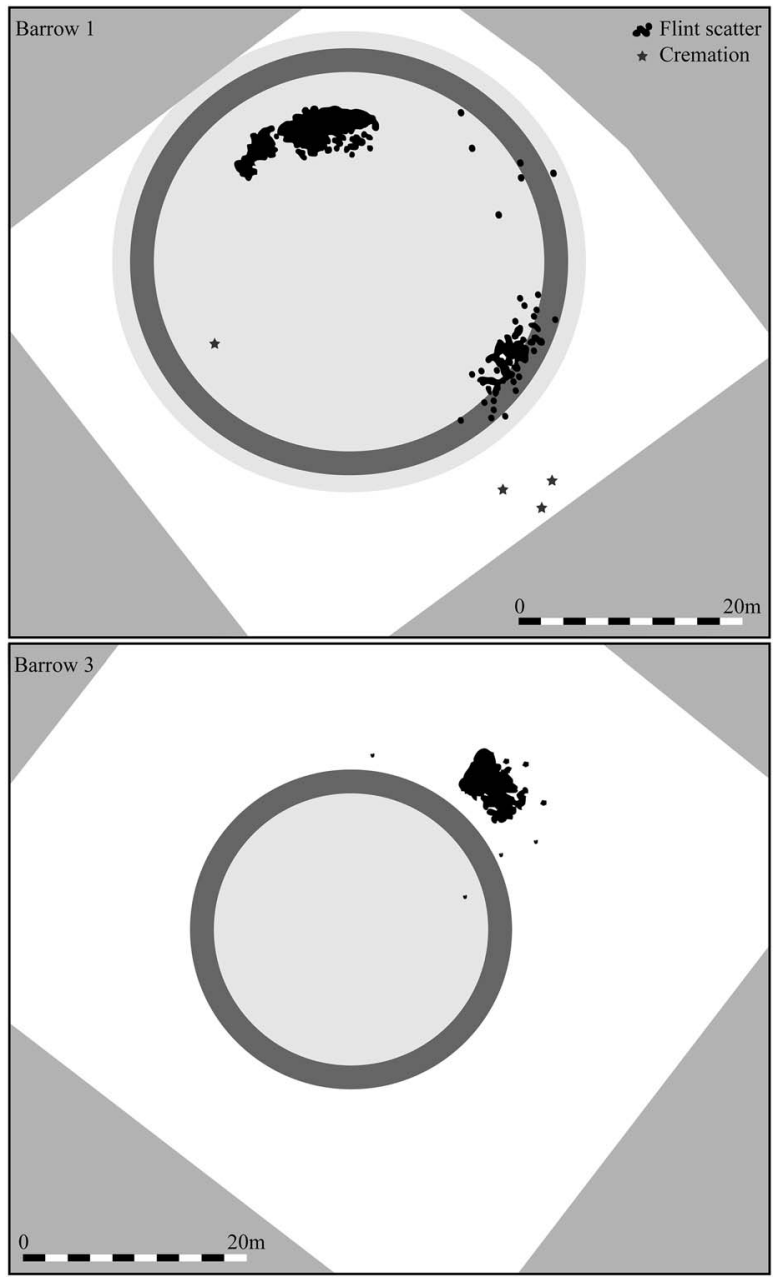

Fig. 7.

Later Bronze Age activity relative to excavated features at Barrows 1 and 3, Irthlingborough (after Healy \& Harding 2007, 187)

\section{Round barrows as active elements of later Bronze Age landscapes}

The evidence from two extensively excavated later Bronze Age landscapes deserves further consideration since it emphasises the interpretative importance of considering the overall makeup of later Bronze Age landscapes in relation to round barrows as well as how specific modes of practice were linked to these existing monuments.

At Over Low Grounds, in a rather unusual setting on an island amidst braided river channels - a Middle Bronze Age landscape developed around an Early Bronze Age cemetery comprising five closely grouped round barrows (three turf-built mounds and two pond 
barrows; Evans et al. forthcoming). A recent intensive programme of radiocarbon dating focusing on the human remains from this barrow cemetery suggests that there was a slight hiatus - perhaps of a couple of hundred years - between earlier and later Bronze Age burial activity at this site in contrast to the relatively 'quick' sequence of interments made during the earlier Bronze Age (Garrow et al. 2014). The land boundaries that developed here not only ultimately 'framed' the existing barrow cemetery, as the published report suggests; they also arguably operated in at least two other ways. Firstly, the layout of these boundaries to a certain extent choreographed movement around the existing monuments - most obviously, a gap in the land boundary to the east of Barrows 14 and 15 structured access to these features. Additionally, these boundaries effectively came to connect the barrow cemetery with the main area of Middle Bronze Age settlement, focused c. $150 \mathrm{~m}$ away on higher ground at the centre of the island.

Perhaps more remarkably, different aspects of this Middle Bronze Age landscape were arguably linked via funerary practices. An unusually wide array of funerary interments of this period was encountered across the excavated area (Fig. 8). Cremations were recovered from the barrow cemetery itself, from the settlement core (including from the post-hole of a round-house), and in association with field boundaries. Middle Bronze Age inhumations were focused within the settlement core. One undated example

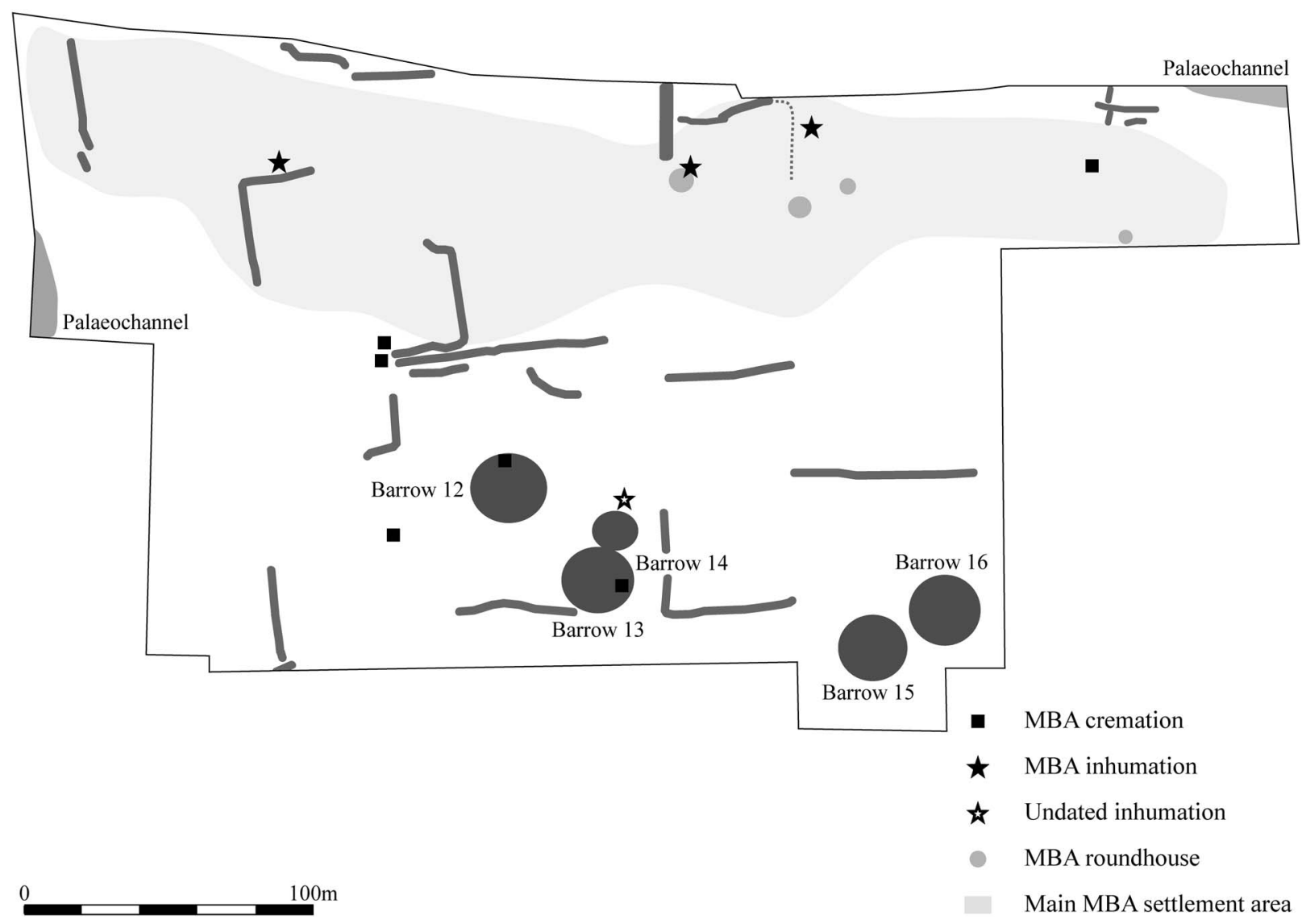

Fig. 8 .

Middle Bronze Age landscape at Over Low Grounds, Cambridgeshire (after Evans et al. forthcoming) 


\section{A. Cooper. ROUND BARROWS IN THE LATER BRONZE AGE OF LOWLAND BRITAIN}

north of Barrow 14 could date to this period, although an Early Bronze Age date seems more likely (Garrow et al. 2014, 214). The existing barrow cemetery was clearly an important part of this Middle Bronze Age landscape - the barrows were not simply 'referenced', 'respected', or 'venerated', and they were certainly not 'replaced' (Yates 2007, 93). Rather, the people who built and occupied this landscape took care to build these features into their lives, almost certainly due partly to the lasting funerary attachments they held. Additionally, this evidence demonstrates clearly that even where existing monuments were held in place (Barrett 1994, 111) within Middle Bronze Age landscapes, the funerary activity with which they were still associated could also be undertaken elsewhere. This accords with Caswell's argument $(2013,76)$ that approaches to funerary practice were perhaps more open-minded in the later Bronze Age, and with Wickstead's suggestion (2008, following Quinnell \& Watts 2002) that practices associated previously with round barrows 'spread out' into the wider landscape during this period. I would add to this that round barrows remained very much a part of this process of broadening out.

A slightly different scenario unfolded in the later Bronze Age fen-edge landscape at Pode Hole Farm (Fig. 9). Here, a more extensive land boundary system developed around an existing barrow cemetery. As at Over Low Grounds, in its final form, this boundary system spanned the area between the barrow cemetery and a dense concentration of later Bronze Age settlement activity at the fen-edge. At Pode Hole Farm, however, very few settlement-related features were located in the immediate vicinity of the barrow cemetery. In fact the one monument that was referred to directly in the later Bronze Age field system (Ring-ditch 1) was located over $200 \mathrm{~m}$ from the nearest settlement concentration. It consequently seems interesting that during the later phases of occupation at this site (c. 1300-800 BC) water-holes were cut into two of these round barrows (Ring-ditches $1 \& 4$; Daniel 2009, 41-3). Significantly, each of the three intercutting water-holes cut into the northern edge of Ringditch 1 produced at least one substantial, and arguably unusual, deposit: these included a large dump of worked structural timbers and half of a tree root bole (Taylor in Daniel 2009, 42); a sizeable deposit of burnt and unburnt animal bone fragments (cattle, pig, sheep, and duck); a bulky and 'near complete' briquetage pedestal (Daniel 2009, 42); and, in the latest feature, an odd assemblage potentially comprising a mix of both Early and Middle Bronze Age material - a thumbnail scraper, Collared Urn fragments, four pieces from a human skull, and a bronze pin and blade, the closest parallels for which are Middle Bronze Age in date (Bevan in Daniel 2009, 43).

The evidence from the water-hole sequence at Ringditch 1 is complex to interpret at a number of different levels. First, it is possible that the human skull fragments within the uppermost water-hole derive from an Early Bronze Age burial that was disturbed when this feature was cut (as was suggested for the human femur recovered from the field boundary terminal cut into the eastern side of the same ring-ditch, see above). Secondly, unusual deposits - sometimes including human fragments and entire or substantial portions of briquetage pedestals - are recovered from later Bronze Age water-holes (and field ditches) elsewhere, whether or not they are associated with ring-ditches; this is the case both within this landscape (Daniel 2009, 50-2) and more broadly (eg, Hutton 2008; Mudd 2008; Crosby \& Muldowney 2011, 27-8; Evans \& Patten 2011, 39-40; Pickstone \& Mortimer 2011). It is certainly possible that the deposits under consideration here were made with direct reference to the water-hole (and the ditch terminal) rather than to the ring-ditch itself.

However at least two factors suggest that the presence of the round barrow was also significant in the development of this water-hole sequence (see also Daniel 2009, 157). Associations between ring-ditches, water-holes, and occasionally also human remains have been observed well beyond this site (eg, Pryor 1978, 61-2; Lambrick et al. 2009, 297). It seems notable that both the water-holes at Ring-ditch 1 and the substantial deposits within them were at least $200 \mathrm{~m}$ from the nearest known settlement (and waterhole) concentration and from the potential saltmaking site at the fen-edge - a considerable distance. In fact, very little material at all was recovered from excavated features elsewhere in the western part of the site (Daniel 2009, 159-60). It is certainly feasible that the material from these deposits derives from a further settlement concentration beyond the investigated area to the west of Ring-ditch 1 . However it seems more likely that this material was brought specifically to this location from further afield (activity areas at the fen-edge).

It is therefore worth considering the option that these deposits were made in a conscious attempt to 


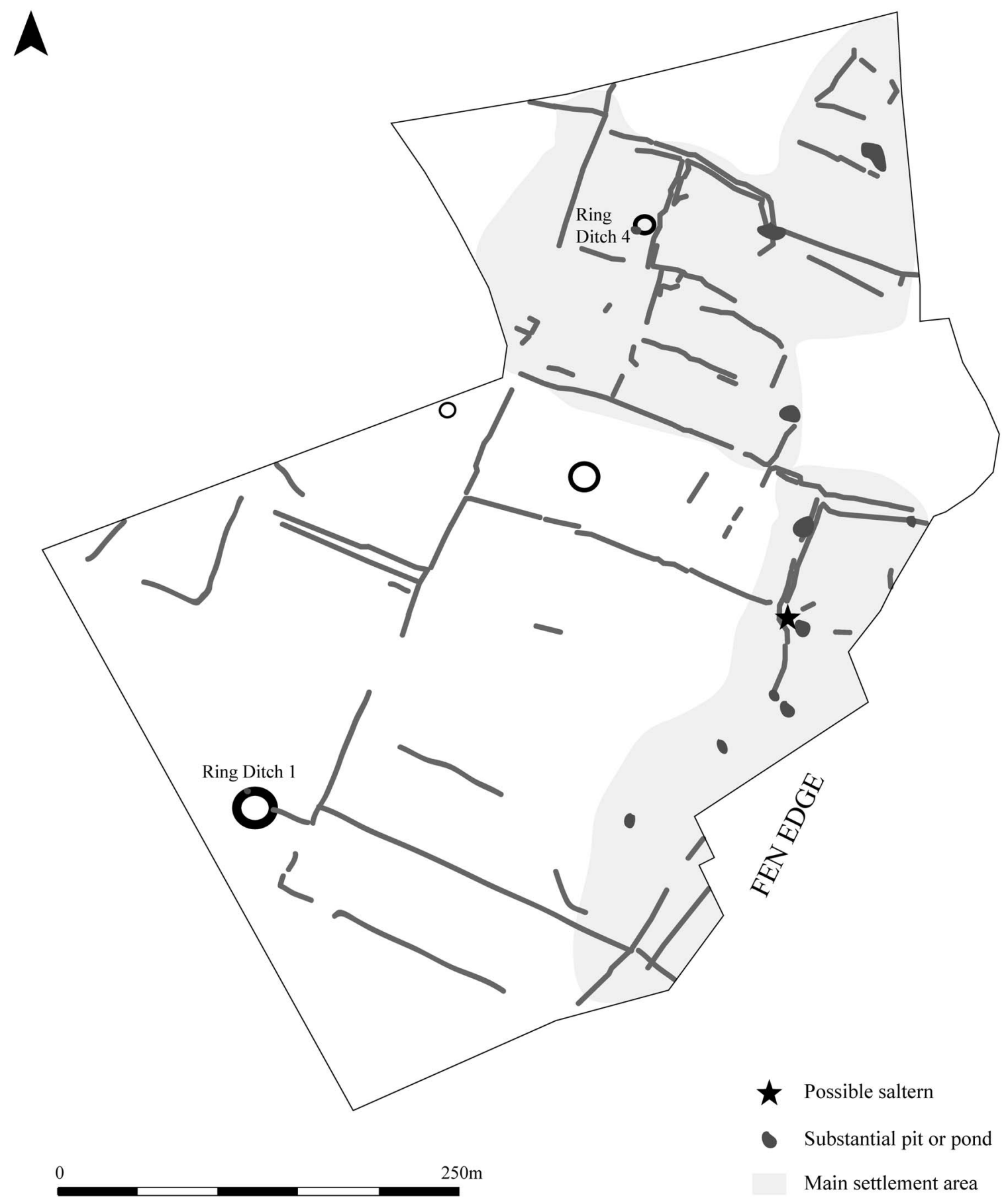

Fig. 9.

Later Bronze Age landscape at Pode Hole Farm, Peterborough (after Daniel 2009, 22)

link both the round barrow and the water-hole materially and conceptually - with the main focus of later Bronze Age settlement activity at the fen-edge.
This interpretation ties in well with Brück's arguments regarding the strong metaphorical and physical associations that developed between human remains, 


\section{A. Cooper. ROUND BARROWS IN THE LATER BRONZE AGE OF LOWLAND BRITAIN}

settlement, and productive activity over the later Bronze Age (Brück 1999; 2000; 2001b). While Brück's work has focused primarily on the occurrence of fragmentary human remains and 'productive material' (metalworking debris, querns, etc) in settlement contexts, it is certainly possible that the deposition of occupation debris, productive material, and possibly also human remains at an existing funerary monument represents an alternative expression of this phenomenon. The potentially widespread association between water-holes, ring-ditches, and unusual deposits certainly deserves further exploration.

\section{Later Bronze Age round barrow landscapes in context}

To finish, it is important to balance the account given above with a consideration of the character of later Bronze Age activity in the study area more broadly. For instance, it is interesting to ask how (if at all) later Bronze Age practices in landscapes without round barrows differed from those that included them, and whether or not round barrows effectively attracted certain kinds of later Bronze Age activity. There is not scope to consider these questions in detail here, but it is worth making a few pertinent points.

At a basic level, we can assess the overall spatial distribution of digital HER records for later Bronze Age activity relative to those for excavated round barrows. Clearly the results of such analysis must be interpreted carefully. ${ }^{11}$ However the finding that over $8 \%$ of all later Bronze Age records are located within $50 \mathrm{~m}$ of an excavated round barrow record seems striking, especially given that this zone constitutes only $0.275 \%$ of the entire study area. This patterning certainly suggests that a significant amount of all later Bronze Age activity occurred in landscape areas that also included round barrows. The attraction of these particular geographical zones for later Bronze Age communities would obviously have gone well beyond their inclusion of round barrows - the presence of major rivers or the fenedge undoubtedly featured strongly. The important point to take from this exercise, however, is that existing round barrows were probably an everyday part of the lives of many later Bronze Age communities, whether or not they were engaged with actively.

Considering in more detail the spatial distribution of records of later Bronze Age activity relative to those for excavated round barrows it is also possible to gain a general sense that certain sorts of practices - the construction of field systems and trackways, roundhouse-associated settlements, salt-production sites, pit alignments, and funerary practices - were typically located closer to round barrows than others (Fig. 10). ${ }^{12}$ Conversely, other modes of practice - including the construction of burnt mounds and deposition of metalwork - tended to be located at a greater distance from topographic zones that included round barrows. Again, this very broad-brush modelling should be interpreted carefully. However, it is noteworthy that the broad locational trends elicited by this diagram do accord with arguments made much more widely (eg, Mullin 2003; Bradley 2007; Yates \& Bradley 2010a).

Perhaps more significantly, this basic assessment shows very clearly that later Bronze Age activities had a geographical range that extended well beyond landscapes that included round barrows - a finding that supports evidence from recent excavations. Fieldwork within eastern England more broadly indicates that during this period, occupation was sometimes established on 'new land' (eg, Hounsell 2007; Evans 2009, 61; Evans \& Patten 2011, 41). This includes relatively upland areas characterised by soil types (clays) that were not typically a focus for earlier occupation, and that seemingly lack substantial Neolithic and Early Bronze Age remains. Within the study area itself, later Bronze Age activity often extended well beyond excavated round barrow sites (see for example evidence from Holme, Colne Fen (Evans et al. 2013), Tower's Fen, Thorney (Mudd 2008), Fengate (Evans 2009), and Godwin Ridge, Over (Evans et al. 2014; forthcoming). Extensive later Bronze Age landscapes seemingly without round barrows have also been excavated in the Peterborough area at Westfield Road (Knight 2002), Eye Quarry (Patten 2004; 2009), and Stanground South (Taylor et al. 2011).

A brief assessment of the evidence from these 'pioneering' (Evans \& Patten 2011, 41) later Bronze Age landscapes is illuminating. Most importantly, in these 'non-barrow' landscapes, it is clear that human remains were deposited in an archaeologically visible way much less often. This point is accentuated if we compare the broad makeup of later Bronze Age evidence within $50 \mathrm{~m}$ of excavated round barrows with that recorded across the whole study area (Fig. 11). Enduring round barrows almost certainly did attract later Bronze Age funerary and ritual activity in the east of England.

Additionally, without immediate access to existing funerary monuments, later Bronze Age communities in 


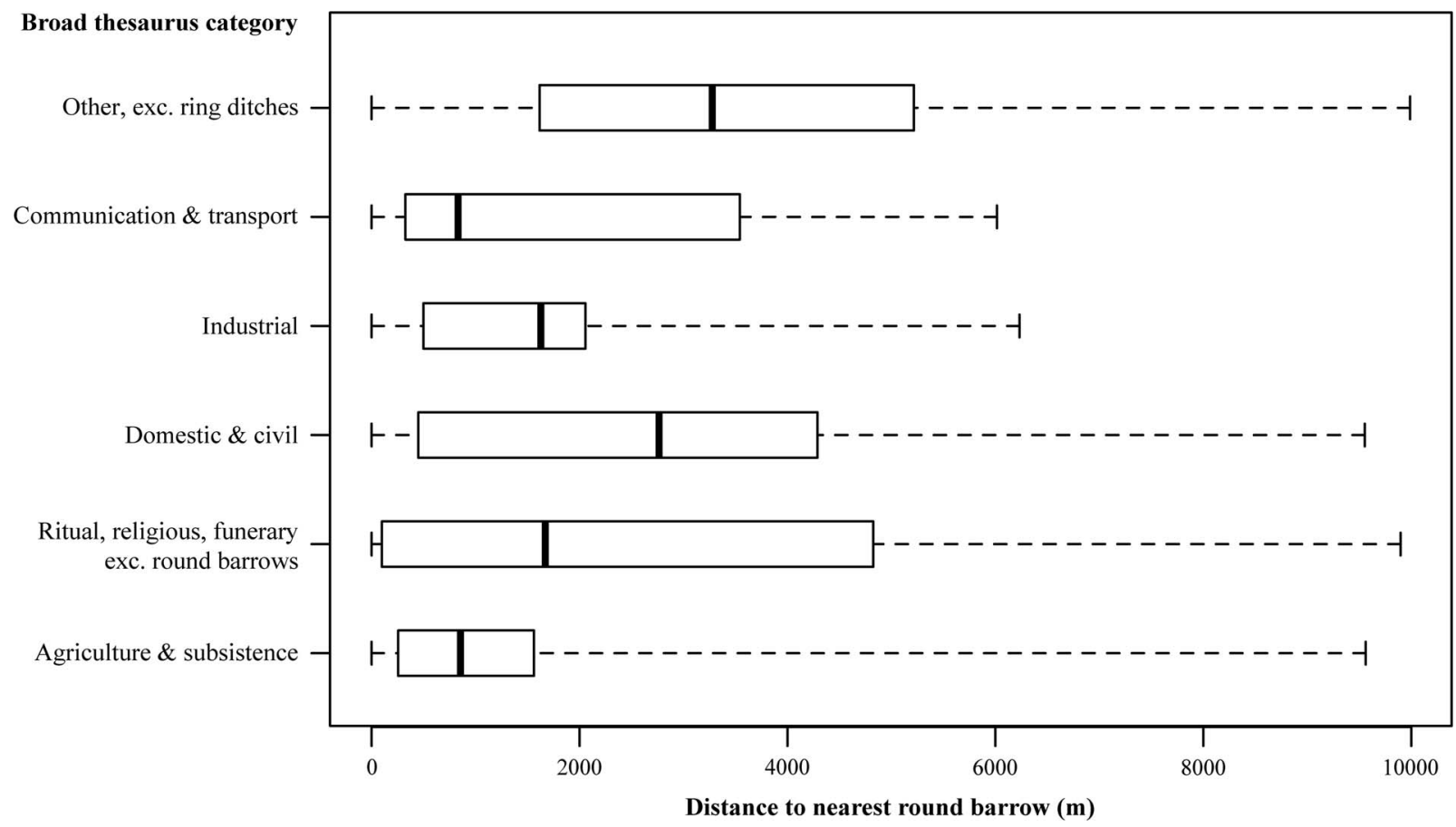

Fig. 10 .

'Box and whisker' plot showing the spatial distribution of records of later Bronze Age activity (organised by broad HE thesaurus classes) relative to the 173 records of excavated round barrows. The thick black line shows the median value for each class; the 'box' shows the interquartile range; the 'whiskers' show the overall distribution of values

these pioneering landscapes necessarily developed a different set of funerary associations. Land boundaries (and to a lesser extent water-holes) were the main foci for cremation burials. Both isolated cremation pits and cemeteries were located immediately adjacent to or cut into field ditches. In some cases cremation groups followed the same broad alignment as nearby boundaries (eg, Patten 2004, 13) or were clustered in field corners. Indeed even within the excavated round barrow landscapes examined in detail here, cremation burials were sometimes located at land boundaries, often slightly detached (more than $100 \mathrm{~m}$ away) from the nearest round barrow - eg, at Rhee Lakeside (South), the Camp Ground, Southern Field Barleycroft, Over Low Grounds, and Stanwick. It is tempting to suggest that over the course of the later Bronze Age, the practice of associating cremations with round barrows was ultimately succeeded by one of associating cremations with land boundaries/water-holes. However available radiocarbon dates from later Bronze Age cremation cemeteries across East Anglia (Robinson 2007, 73) and evidence for cremation practices more broadly (Caswell 2013) suggest that the temporal relationship between these two burial traditions is more complex.

This strong association between later Bronze Age human remains and land boundaries is noteworthy in eastern England and almost certainly more widely (eg, Bradley 2007, 189; Cooper \& Edmonds 2007, 93; Robinson 2007; Hutton 2008, 4-6; Caswell 2013, 68) for several reasons. First, it raises the interesting possibility that, as well as undoubtedly fulfilling other purposes, in certain contexts land boundaries operated as an alternative form of funerary monument. This interpretation is particularly compelling given that land boundaries are already often viewed as being in some ways monumental (see above). This situation also draws comparison with the evidence from upland Bronze Age landscapes where it is often noted that it is very difficult to distinguish between 'funerary' and 'agricultural' monuments (in this case usually cairns), not least because fragmentary human remains can occur in both (Johnston 2001; Kitchen 2001; Williams 2003; Wickstead 2008). Secondly, this finding 


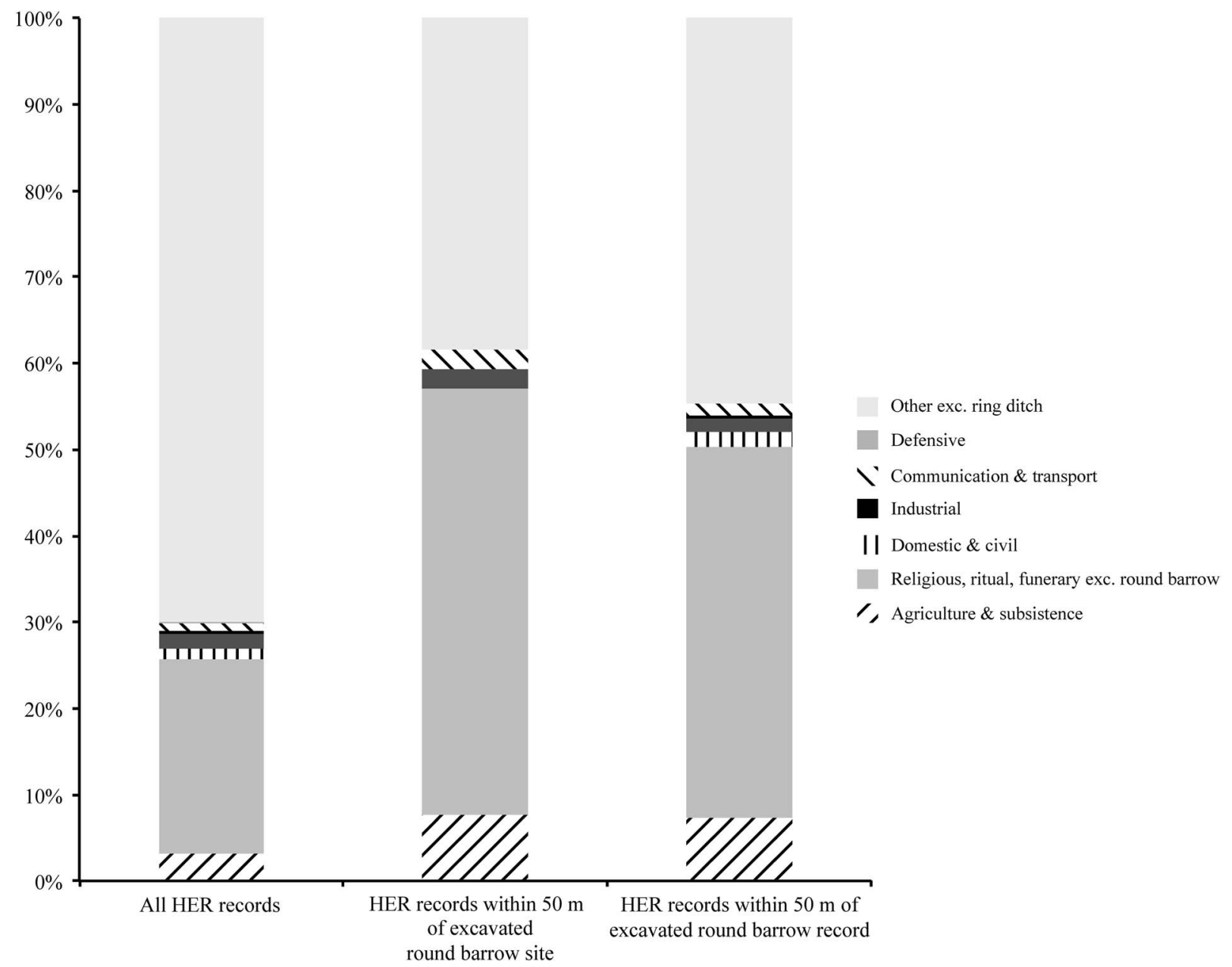

Fig. 11.

Comparison of the makeup of later Bronze Age activity within $50 \mathrm{~m}$ of records of excavated round barrows \& that within the study area as a whole

supports the suggestion made earlier that Middle Bronze Age land boundaries acted in some ways as bridging devices. As well as commonly linking existing round barrows and later Bronze Age settlement in a physical sense, over time they came to connect these two elements of later Bronze Age landscapes in a funerary sense. Land boundaries were an important focus for burial activity in the period (the Middle Bronze Age) between when human remains were primarily deposited at round barrows (the Early Bronze Age) and when settlement features were also important funerary contexts (the Late Bronze and Iron Age; Brück 1995; 2001b).

Finally it is worth commenting briefly on one key mode of practice that was not generally associated with existing round barrows in the later Bronze Age. At a broad level, the lack of spatial correspondence between finds of later Bronze Age metalwork and round barrows is striking (Fig. 12). This strongly supports arguments made in recent years (eg, Mullin 2003, 127; Bradley 2007, 184-5; Yates \& Bradley 2010b) that watery places and hoards (not round barrows) were the main foci for metalwork deposits during the later Bronze Age. However it is much more complex to assess the extent to which the spatial separation of round barrows and burnt mounds/metalwork deposits is a particular feature of the later Bronze Age in this region (eg, Pendleton 1999; see also Frieman 2014 since flint daggers should arguably be viewed alongside metal ones in the earliest Bronze Age). 


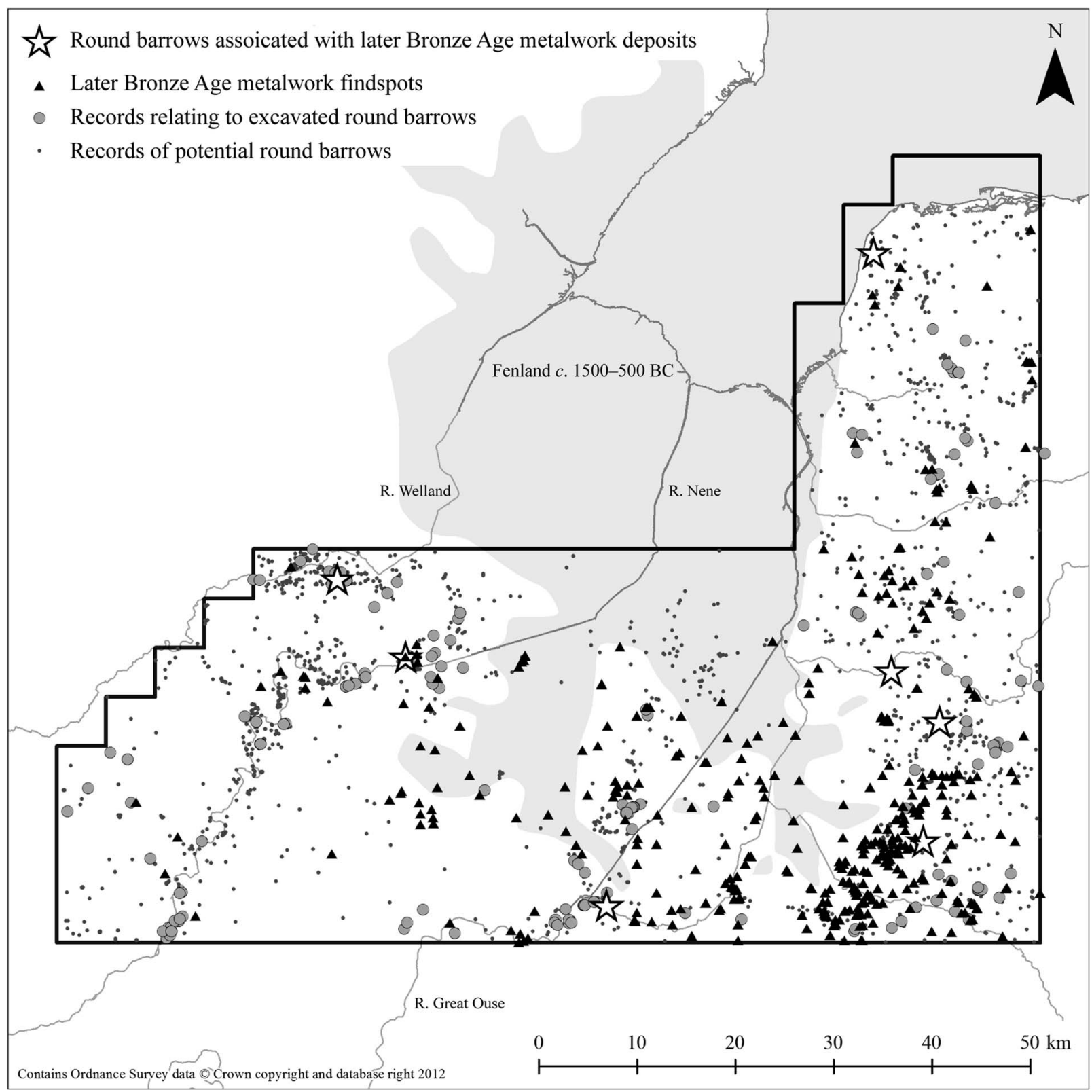

Fig. 12.

Spatial distribution of later Bronze Age metalwork findspots relative to records of excavated round barrows

DISCUSSION: ROUND BARROWS AND WIDER UNDERSTANDINGS OF THE LATER BRONZE AGE

This study has shown very clearly that in certain parts of lowland Britain (and possibly much more broadly) round barrows were an active part of later Bronze Age lives in various ways. It is important to stress that most activities undertaken at round barrows during this period were also undertaken in a range of other contexts. However round barrows appear to have attracted certain kinds of (mainly funerary and ritual) practice. Additionally, in certain landscapes there is a strong sense that people actively sought to include barrows in the broader fabric of life: they were held in place. 


\section{A. Cooper. ROUND BARROWS IN THE LATER BRONZE AGE OF LOWLAND BRITAIN}

Returning to the existing understandings of round barrows in the later Bronze Age outlined at the beginning of this paper, it is clear that fundamental shifts took place in the role of these monuments over the course of the 2nd millennium (eg, Barrett 1994, 151). According to the findings presented here, however, it no longer seems possible to argue straightforwardly that round barrows were 'no longer an effective way of communicating relationships with the dead' in the later Bronze Age (Bradley 2007, 201). Nor can it easily be contended that the systems of land holding represented by round barrows (Yates 2007, 93), or their role as sensitive loci for material and ideological investment (Brück 2000, 285), were simply 'replaced' by other aspects of later Bronze Age landscapes. This study does not, of course, represent later Bronze Age activities at round barrows in Britain as a whole. However the findings of this analysis, together with Johnston's arguments (2001; 2005) regarding the important role played by enduring structures in upland England, make it seem very important that, in future, round barrows are considered as a matter of course in studies of later Bronze Age life alongside land boundaries, cremation cemeteries, settlement activity, and metalwork deposits.

It is also worth commenting briefly on the shifting role of round barrows over the course of the later Bronze Age. At one level it is difficult to discuss this topic in detail due to the paucity of specifically Late Bronze Age activity at round barrows in the study area. This theme might best be approached through a long-term comparison of the development of landscapes 'with' and 'without' barrows over the duration of the later Bronze Age. Based on the findings presented here, however, it is clear that round barrows were a focus for activity much less often in the Late than in the Middle Bronze Age. Although the overall range of activities undertaken at round barrows is similar throughout the later Bronze Age, there is also a broad shift in the overall emphasis of the practices involved over this period. Whereas in the Middle Bronze Age strong relationships (including spatial, physical, formal, and conceptual dimensions) clearly developed between barrows, fields, and funerary practices, in the Late Bronze Age this relationship appears to have dissipated. Instead, settlement was the commonest mode of activity located at round barrows, and there is little evidence to suggest that the monuments themselves were engaged with directly.
As well as furthering considerably our understanding both of what did sometimes happen at round barrows in eastern England in the later Bronze Age (see Cooper forthcoming for an overview of the subtly different chronologies elsewhere in England), and of the ways in which round barrows were tied into other practices, this study adds significantly to much wider understandings of the later Bronze Age. Adding important context, recently excavated evidence, and a subtly different perspective to Robinson's (2007) and Caswell's (2013) work specifically on later Bronze Age cremations, the findings presented here suggest that a balanced account of funerary practices during this period must take into account activities undertaken at round barrows. Although novel (archaeologically less visible) burial practices did emerge during the later Bronze Age (Brück 1995; 1999; 2001b), it is clear that formal burials were still frequently made at existing funerary monuments. This study raises, for the first time, the possibility that not only were human remains incorporated into later Bronze Age settlement contexts (as Brück argued), but that settlement debris (including human remains) was also sometimes deposited at existing funerary monuments, sometimes far from the settlement. Additionally the findings provide convincing evidence of the monumental properties of land boundaries, and not only in the sense that they represent substantial communal building projects (eg, Yates 2007). Since later Bronze Age burials were regularly associated directly with these features - much as they were associated with existing round barrows land boundaries may also have operated as a novel form of funerary monument. In both of the above cases, the evidence examined adds important nuance and rich texture to recent discussions regarding the mingling of 'ritual' and 'everyday' practices in the later Bronze Age (eg, Brück 1995; 1999; 2001b; Williams 2003).

The suggestion that particular sets of practices emerged within particular landscape zones during this period adds detail to existing arguments that, over the course of the Bronze Age, people developed more sustained and potentially more exclusive attachments to specific areas of the landscape (eg, Barrett 1994, 145-7). It also offers tangible evidence of the different scales at which communities of practice operated (Cohen 1985; see also Gerritsen 2003). In the east of England, it appears that specific ideas about how to bury human remains at round barrows were shared at a valley-wide scale (cf. Evans \& Appleby 2008). Meanwhile understandings of how to deal with 
enduring round barrows during the construction of field systems were devised more locally. Consequently, in drawing on evidence from a study area that has benefited from extensive high-quality excavations over a sustained time period ( 25 years and more), this study arguably sheds light in specific ways on how new understandings of place and certain kinds of identities were produced in later Bronze Age landscapes (cf. Johnston 2001; 2005, 13).

Finally, the analysis set out above provides a vital context for a growing body of work examining the extended trajectories of round barrow landscapes on the near Continent, mainly in the Low Countries. In brief, it is important to highlight the fact that Bronze Age landscapes in the Low Countries are distinctly different in their makeup and chronology to those in lowland Britain. For instance barrows (and later urnfields) were built in distinct waves over a much longer time period (from $2800 \mathrm{BC}$ to the Early Roman period). Additionally from $1500 \mathrm{BC}$ onwards settlements are more prominent, and field systems often lack the scale and regularity of those that developed in parts of lowland Britain (see Bourgeois 2013; Van Beek \& De Mulder 2014; Bradley et al. 2016 for excellent summaries). A different set of interpretative issues has therefore necessarily arisen. The findings presented here suggest, however, that round barrow histories in eastern England accord much more closely with those in the Low Countries than has previously been recognised. In both contexts, it is clear that round barrows were engaged with intermittently for various purposes well beyond their initial construction and use. The overall character of activities undertaken at Low Countries round barrows in the Late Bronze Age (1100-800 BC; eg, Van Beek \& De Mulder 2014, 303) resembles closely that discussed for the later Bronze Age in eastern England. There are also several specific points of connection. A close association between extensive wooden post alignments and round barrows in the early 1st millennium $\mathrm{BC}$ has been observed in both contexts (eg, Fokkens 2012, 563; Evans 2009; Evans et al. forthcoming). Bourgeois $(2013,199)$ also notes that broad modes of Late Bronze Age practice at round barrows (eg, cremation burial) were enacted in particular ways within specific landscape areas, as was observed in this study.

Overall, it is clear that the assemblage of activities undertaken at round barrows in lowland Britain changed in the later Bronze Age, as did undoubtedly people's understandings of these features. Drawing on the richness of the excavated evidence from eastern England, I hope to have shown that in certain geographical areas this involved a shift in emphasis rather than any clear sense of demise - round barrows were very much held in place and were reconfigured in relation to wider developments during this period. Ultimately, this study bolsters existing approaches that have emphasised the multi-temporal character of later prehistoric landscapes, and the importance of questioning how different aspects of these topographies inter-relate.

Acknowledgements: This study was conducted as part of the European Research Council-funded English Landscape and Identities Project, University of Oxford. The data were collated from Cambridgeshire, Norfolk, Northamptonshire, Peterborough, and Suffolk HERs, Historic England, the Archaeological Investigations Project, the Archaeological Data Service, and the Portable Antiquities Scheme. It goes without saying that this work would not have been possible without the support and expertise of the many professionals involved in curating and extracting these data for the EngLaID project. I am especially grateful to Sally Croft (Cambridgeshire HER), Christine Addison (Northamptonshire HER), Sarah Botfield and Rebecca CasaHatton (Peterborough HER), Richard Hoggett (Suffolk HER), and Heather Hamilton (Norfolk HER) who offered advice on the specificities of their data and provided supplementary information. The study has benefited greatly from discussions with archaeologists from Cambridge Archaeological Unit (Grahame Appleby, Chris Evans, Mark Knight), Phoenix Consulting Archaeology Limited (Gary Coates), and Suffolk Archaeology (Jo Caruth). Fraser Sturt (Southampton University) provided images of the prehistoric fenland taken from his published models of North West European Holocene palaeogeography and inundation (Sturt et al. 2013). Ed Caswell (Durham University) and Chris Evans and Iona Robinson (Cambridge Archaeological Unit) generously shared unpublished material with me. The ideas put forward were developed through discussions with other members of the EngLaID project team - Miranda Creswell, Vicky Donnelly, Tyler Franconi, Chris Gosden, Chris Green, Letty Ten Harkel, Sarah Mallet, Laura Morley, and Dan Stansbie. Chris Green also undertook the data processing for Figs $10 \& 11$, and assisted greatly with finalising the remaining figures. Finally I would like to thank Chris Evans, Duncan Garrow, and Chris Gosden for commenting insightfully, as ever, on earlier versions of this text, and the three anonymous referees for suggesting further helpful refinements.

\footnotetext{
Endnotes

${ }^{1}$ See Barnatt 1999; Bradley 2007; Harding 2000; Johnston 2001; Kitchen 2001; and Spratt \& Atherden 1993 for overviews of the subtly different sequence and makeup of evidence for this period in the north-west of Britain and the
} 


\section{A. Cooper. ROUND BARROWS IN THE LATER BRONZE AGE OF LOWLAND BRITAIN}

correspondingly different (if related) interpretative narratives that have arisen.

2 This paper focuses specifically on round barrow relationships in the later Bronze Age. However this subset of data was taken from a much broader study of round barrow relationships spanning the period from 1500 BC-AD 1086, conducted as part of the ERC-funded English Landscape and Identities project (EngLaID), University of Oxford (Cooper forthcoming).

${ }^{3}$ Throughout this study 'round barrow' is used as a coverall term for both 'round barrows' and 'ring-ditches'. These two monument forms could potentially have operated in different ways both in the Bronze Age and in later periods (Evans et al. forthcoming). However in practice it is often very difficult to determine conclusively whether or not a 'ringditch' excavated recently would have lacked a mound in prehistory. Both monument forms are therefore treated together here.

4 Throughout the analysis, the term 'excavated round barrow' denotes those that have been verified by any form of intrusive fieldwork - full or partial excavation, trial trenching, watching briefs, test pits, coring, etc. Round barrow 'sites' (as in specific coherent 'groups' of barrows) are notoriously difficult to define (eg, Fleming 1971, 143; Bourgeois 2013,13-14). This is particularly the case in the east of England where round barrows are often widely spaced over extensive areas, conforming to definitions for 'dispersed' or 'area' barrow cemeteries (Fleming 1971, 141). In most cases the barrow sites identified for this study were clear-cut. Within extensive excavated landscapes that included several possible groupings of round barrows (eg, at Raunds and Barleycroft/Over), separate sites were defined where individual round barrows or groups were spatially distinct or where they were isolated topographically (eg, they were located on an island).

${ }^{5}$ See Appendix S1 for a full list of the 40 'sites' examined in detail and how these relate to the 53 source records and 87 separate excavated round barrows. Thirty-one of these sites were represented in more than one consulted data source. In these cases, the Source_ID given in Appendix S1 is preferentially the HER ID. Source IDs from the NRHE, OASIS, and the BIAB are given only where the round barrow site was not represented by an HER record. No directly relevant source ID was identified for the segmented ditch circle at Stanwick the Source_ID given for this monument in Appendix S1 is actually that for the immediately adjacent Neolithic causewayed ring-ditch. Overall, the structure of these data is necessarily complicated, reflecting the complex histories via which evidence relating to barrows has been produced and recorded over at least a 150 year period (Cooper \& Green 2016). The full dataset will be available via the ADS from 2017, following completion of the EngLaID project.

${ }^{6}$ Only 91 of the 173 digital records relating to excavated round barrows in the study area were linked to reports that were both accessible and potentially included sufficiently detailed information. Many sites in Suffolk and Norfolk were excavated in the late 19th and early 20th centuries - no formal report was produced. Several of the excavated sites for which reports were accessible were investigated only very minimally (eg, during trial trenching or watching briefs) the information available for these sites was too basic to merit detailed consideration.

7 The 'monument types' and 'monument classes' referred to in this study relate to 'types' and 'classes' of archaeological activity at a broad level (eg, the 'types' round-house, artefact scatter etc or the 'classes' agriculture and subsistence, domestic etc) as they are recorded in regional HERs and in the NRHE, rather than to 'types' or 'classes' of prehistoric monuments (eg, bell barrow, pond barrow etc).

${ }^{8}$ With one exception - 'development of an existing round barrow' - the 'evidence type' and 'broader monument' classes were drawn from 'monument type' and 'broad thesaurus' classes defined for the purposes of the EngLaID project (see Cooper \& Green 2016 for a more detailed summary). In producing Figure 2, distinct episodes of the same type of activity (eg, cremation burials) at one round barrow site were logged only once. The main aim was to produce a basic 'snapshot' of the kinds of activity represented at each site.

${ }^{9}$ In no case has the precise period over which these cemeteries were created been ascertained.

10 This site has not yet been published. However the author co-directed one phase of the excavation and has discussed subsequent findings with the Cambridge Archaeological Unit team who, together with the University of Cambridge, are working towards publishing the site (see Fig. 10).

${ }^{11}$ In plotting digital HER records archaeological entities that cover extensive areas (eg, field systems) are necessarily (but unrealistically) treated as 'dots on maps'. By considering the overall distribution of known later Bronze Age activity relative only to excavated round barrows a very particular vision of this relationship is produced that would undoubtedly be refined through further fieldwork. Additionally it is important to highlight that excavations themselves have a specific set of topographic and cultural associations (eg, they are frequently undertaken in advance of gravel extraction and thus, like round barrows, tend to be located along major river valleys). The assessment presented here therefore represents the known distribution of later Bronze Age activity relative to verified round barrows. How this patterning relates to the 'true' distribution requires further testing.

12 Figure 10 shows only the spatial patterning of later Bronze Age activity relative to records of excavated round barrows organised by broad HE 'thesaurus classes'. The plot of specific 'monument types' (eg, pit alignments) relative to records of excavated round barrows would be unreadable on a printed page. 


\section{SUPPLEMENTARY MATERIAL}

To view supplementary material for this article, please visit http://dx.doi.org/10.1017/ppr.2016.9

\section{BIBLIOGRAPHY}

Appleby, J. 2013. Temporality and the transition to cremation in the late third millennium to mid second millennium BC in Britain. Cambridge Archaeological Journal 23(1), 83-97

Barrett, J. 1994. Fragments from Antiquity: An archaeology of social life in Britain, 2900-1200 BC. Oxford: Blackwell

Barrett, J. 1999. Chronologies of landscape. In P. Ucko \& R. Layton (eds), The Archaeology and Anthropology of Landscape, 21-30. London: Routledge

Barnatt, J. 1999. Taming the land: Peak District farming and ritual in the Bronze Age. Derbyshire Archaeological Journal 119, 19-78

Bevan, L. 2009. Copper alloy objects from pit 4046. In Daniel 2009, 43

Bjarke Ballin, T. 2007. Post-mound flint industries from Barrows 1 and 3. In Harding \& Healy 2007, 187-8

Bourgeois, Q. 2013. Monuments on the Horizon: The formation of the barrow landscape throughout the $3 \mathrm{rd}$ and 2 nd millennium $B C$. Unpublished $\mathrm{PhD}$ thesis. Leiden University.

Bourgeois, Q. \& Fontijn, D. 2008. Houses and barrows in the Low Countries. In S. Arnoldussen \& H. Fokkens (eds), Bronze Age Settlements in the Low Countries, 41-57. Oxford: Oxbow Books

Bradley, R. 1981. Various styles of urn: Cemeteries and settlement in southern England, c. 1400-1000 b.c. In R. Chapman, I. Kinnes \& K. Randsborg (eds), The Archaeology of Death, 93-104. Cambridge: Cambridge University Press

Bradley, R. 2007. The Prehistory of Britain and Ireland. Cambridge: Cambridge University Press

Bradley, R., Entwhistle, R. \& Raymond, F. 1994. Prehistoric Land Divisions on Salisbury Plain: The work of the Wessex Linear Ditches Project. London: English Heritage

Bradley, R., Haselgrove, C., Vander Linden, M. \& Webley, L. 2016. The Later Prehistory of Northwest Europe: The evidence of recent fieldwork. Oxford: Oxford University Press

Brück, J. 1995. A place for the dead: The role of human remains in late Bronze Age Britain. Proceedings of the Prehistoric Society 61, 245-77

Brück, J. 1999. Houses, lifecycles and deposition on Middle Bronze Age settlements in southern England. Proceedings of the Prehistoric Society 65, 145-66

Brück, J. 2000. Settlement, landscape and social identity: The Early-Middle Bronze Age transition in Wessex, Sussex and the Thames Valley. Oxford Journal of Archaeology 19(3), 273-300

Brück, J. (ed.) 2001a. Bronze Age Landscapes: Tradition and transformation. Oxford: Oxbow Books

Brück, J. 2001b. Body metaphors and technologies of transformation in the English Middle and Late Bronze Age. In Brück 2001a, 149-60
Brück, J. 2004. Material metaphors: The relational construction of identity in Early Bronze Age burials in Ireland and Britain. Journal of Social Archaeology 4(3), 307-33

Brück, J. 2007. The character of Late Bronze Age settlement in southern Britain. In C. Haselgrove \& R. Pope (eds), The Earlier Iron Age in Britain and the Near Continent, 24-38. Oxford: Oxbow Books

Caswell, E. 2013. Bodies, Burnings and Burials: Analysing Middle Bronze Age cremations in Britain. Unpublished MA thesis. University of Durham

Chapman, A. 1997. The excavation of Neolithic and medieval mounds at Tansor crossroads, Northamptonshire 1995. Northamptonshire Archaeology 27, 3-50

Cohen, A. 1985. The Symbolic Construction of Community. Chichester: Ellis Horwood

Connerton, P. 1989. How Societies Remember. Cambridge: Cambridge University Press

Connor, A. \& Mortimer, R. forthcoming. Prehistoric and Roman Occupation Along Fordham Bypass, Fordham, Cambridgeshire. Norwich: East Anglian Archaeology

Cooper, A. forthcoming. Temporality. In A. Cooper, V. Donnelly, T. Franconi, C. Gosden, C. Green, L. Ten Harkel, Z. Kamash, S. Mallet, L. Morley \& D. Stansbie (eds), English Landscapes and Identities: Investigating landscape change from $1500 B C$ to $A D$ 1086. Oxford: Oxford University Press

Cooper, A. \& Edmonds, M. 2007. Past and Present: Excavations at Broom, Bedfordshire 1996-2005. Cambridge: Cambridge Archaeological Unit

Cooper, A. \& Green, C. 2016. Embracing the complexities of 'big data' in archaeology: The case of the English Landscape and Identities project. Journal of Archaeological Method and Theory 23(1), 271-304

Crosby, V. \& Muldowney, L. 2011. Stanwick Quarry, Northamptonshire: Raunds Area Project. Phasing the Iron Age and Romano-British settlement at Stanwick, Northamptonshire (excavations 1984-1992): Archaeological report. Portsmouth: English Heritage

Daniel, P. 2009. Archaeological Excavations at Pode Hole Quarry: Bronze Age occupation on the Cambridgeshire Fen-edge. Oxford: British Archaeological Report 484

Ellis, P., Coates, G., Cuttler, R. \& Mould, C. 2001. Four Sites in Cambridgeshire: Excavations at Pode Hole Farm, Paston, Longstanton and Bassingbourn, 1996-7. Oxford: British Archaeological Report 322

Ellison, A. 1978. The Bronze Age in Sussex. In P. Drewett (ed.), Archaeology in Sussex to AD 1500, 30-7. London: Council for British Archaeology

Ellison, A. 1980. Deverel-Rimbury urn cemeteries: The evidence for social organisation. In J. Barrett \& R. Bradley (eds), The Later British Bronze Age, 115-26. Oxford: British Archaeological Report 8

English, J. 2013. Pattern and Progress: Field systems of the second and early first millennia $B C$ in southern Britain. Oxford: British Archaeological Report 587

Evans, C. 2009. Fengate Revisited: Further Fen-edge excavations, Bronze Age fieldsystems/settlement and the Wyman Abbott/Leeds Archives. Cambridge: Cambridge Archaeological Unit 


\section{A. Cooper. ROUND BARROWS IN THE LATER BRONZE AGE OF LOWLAND BRITAIN}

Evans, C. \& Appleby, G. 2008. Historiography and fieldwork: Wyman Abbott's great Fengate ring-ditch (a lost manuscript found). Proceedings of the Prehistoric Society 74, 171-92

Evans, C., Brudenell, M., Patten, R. \& Regan, R. 2013. Process and History: Prehistoric communities at Colne Fen, Earith, Bronze Age fieldsystems, ring-ditch cemeteries and Iron Age settlement. Cambridge: Cambridge Archaeological Unit

Evans, C. \& Hodder, I. 2006. Marshland Communities and Cultural Landscapes from the Bronze Age to the Present Day. Cambridge: MacDonald Institute for Archaeological Research

Evans, C. \& Knight, M. 1998. The Butcher's Rise RingDitches: Excavations at Barleycroft Farm, Cambridgeshire. Cambridge: Cambridge Archaeological Unit, Report 283

Evans, C. \& Knight, M. 2000. A fenland delta: Later prehistoric landuse in the lower Ouse Reaches. In M. Dawson (ed.), Prehistoric, Roman and Post-Roman Landscapes of the Great Ouse Valley, 89-96. York: Council for British Archaeology Research Report 119

Evans, C. \& Knight, M. 2001. The 'community of builders': The Barleycroft post alignments. In Brück 2001a, 83-98

Evans, C. \& Patten, R. 2011. An inland Bronze Age: Excavations at Striplands Farm, West Longstanton. Proceedings of the Cambridge Antiquarian Society 100, $7-45$

Evans, C. \& Pollard, J. 1995. The Excavation of a Ringditch and Prehistoric Fieldsystem at Barleycroft Farm, Bluntisham, Cambridgeshire. Cambridge: Cambridge Archaeological Unit, Report 126

Evans, C., Tabor, J. \& Vander Linden, M. 2014. Making time work: Sampling floodplain artefact frequencies and populations. Antiquity 88, 241-58

Evans, C., Tabor, J. \& Vander Linden, M. forthcoming. Twice-crossed River: Prehistoric and palaeoenvironmental investigations at Barleycroft Farm/Over, Cambridgeshire (The Archaeology of the Lower Ouse Valley, Volume III). Cambridge: Cambridge Archaeological Unit

Fennell, K.R. 1961. Excavations at O.S. 38, Tallington. Lincolnshire Architectural and Archaeological Society Reports and Papers 9(1), 26-34

Fleming, A. 1971. Territorial patterns in Bronze Age Wessex. Proceedings of the Prehistoric Society 37, 138-66

Fokkens, H. 2012. Access to origins: About the meaning of continuity and discontinuity in the use of barrow 'cemeteries'. In D. Bérenger, J. Bourgeios, M. Talon \& S. Wirth (eds), Gräberlandschaften Der Bronzezeit. Internationales Kolloquium Zur Bronzezeit, Herne, 15-18 Oktober 2008, 553-71. Darmstadt: Von Zabern

Fontijn, D. 1996. Socialising landscape: Second thoughts about the cultural biography of urnfields. Archaeological Dialogues 3(1), 77-87

French, C. 1994. Excavation of the Deeping St Nicholas Barrow Complex, South Lincolnshire. Sleaford: Heritage Trust of Lincolnshire

Frieman, C. 2014. Double edged blades: Re-visiting the British (and Irish) flint daggers. Proceedings of the Prehistoric Society 80, 33-65
Garrow, D. 2012. Odd deposits and average practice: A critical history of the concept of structured deposition. Archaeological Dialogues 19(2), 85-115

Garrow, D., Meadows, J., Evans, C. \& Tabor, J. 2014. Dating the dead: A high-resolution radiocarbon chronology of burial within an Early Bronze Age barrow cemetery at Over, Cambridgeshire. Proceedings of the Prehistoric Society 80, 207-36

Garwood, P. 2007. Before the hills in order stood: Chronology, time and history in the interpretation of Early Bronze Age round barrows. In Last 2007a, 30-52

Germany, M. 2007. Neolithic and Bronze Age Monuments and Middle Iron Age Settlement at Lodge Farm, St Osyth, Essex: Excavations 2000-3. Chelmsford: Essex County Council

Gerritsen, F. 2003. Local Identities: Landscape and community in the late prehistoric Meuse-Demer-Scheldt region. Amsterdam: Amsterdam University Press

Gerritsen, F. 2007. Familiar landscapes with unfamiliar pasts? Bronze Age barrows and Iron Age communities in the southern Netherlands. In C. Haselgrove \& R. Pope (eds), The Earlier Iron Age in Britain and the Near Continent, 338-53. Oxford: Oxbow Books

Gibson, C. 2004. Lines In The Sand: Middle to Late Bronze Age settlement at Game Farm, Downham Way, Brandon. Norwich: East Anglian Archaeology Occasional Paper 19 Giles, M. 2012. A Forged Glamour: Landscape, identity and material culture in the Iron Age. Oxford: Windgather Press

Gilmour, N., Horlock, S., Mortimer, R. \& Tremlett, S. 2014. Middle Bronze Age enclosures in the Norfolk Broads: A case study at Ormesby St Michael, England. Proceedings of the Prehistoric Society 80, 141-57

Harding, J. 2000. Northern Pasts: Interpretations of the later prehistory of Northern England and Southern Scotland. Oxford: British Archaeological Report 302

Harding, J. \& Healy, F. 2007. A Neolithic and Bronze Age Landscape in Northamptonshire: The Raunds Area Project. Swindon: English Heritage

Healy, F. \& Harding, J. 2007. A thousand and one things to do with a round barrow. In Last 2007a, 53-71

Helms, M. 1988. Ulysses' Sail: An ethnographic odyssey of power, knowledge, and geographical distance. Princeton: Princeton University Press

Holst, M., Rasmussen, M., Kristiansen, K. \& Bech, J. 2013. Bronze Age 'Herostrats': Ritual, political, and domestic economies in Early Bronze Age Denmark. Proceedings of the Prehistoric Society 79, 265-96

Hounsell, D. 2007. Papworth Everard Bypass Project: Postexcavation assessment and updated project design. Cambridge: Cambridgeshire County Council Archaeological Field Unit, Report 971

Humphrey, J. 2004. Iron Age Flint Utilisation in Central and Southern Britain: The last "Stone Age?" An integrated theoretical and empirical study. Unpublished $\mathrm{PhD}$ thesis. University of Leicester.

Hunn, J. 1992. An Archaeological Evaluation at Block Fen (A), Mepal, Cambridgeshire. Oxford: Tempus Reparatum, Report 1456 
Hutton, J. 2008. Excavation at Langtoft, Lincolnshire: The Freeman Land. Cambridge: Cambridge Archaeological Unit, Report 838

Ingold, T. 1993. The temporality of the landscape. World Archaeology 25(2), 152-74

Johnston, R. 2001. 'Breaking new ground': Land, tenure and fieldstone clearance during the Bronze Age. In Brück 2001a, 99-109

Johnston, R. 2005. Pattern without a plan: Rethinking the Bronze Age coaxial field systems on Dartmoor, south-west England. Oxford Journal of Archaeology 24(1), 1-21

Jones, A.M. 2005. Cornish Bronze Age Ceremonial Landscapes c. 2500-1500 BC. Oxford: British Archaeological Report 394

Kitchen, W. 2001. Tenure and territoriality in the British Bronze Age: A question of varying social and geographic scales? In Brück 2001a, 110-20

Knight, M. 2002. New Prison at Former Rockwell and APV Works, Westfield Road, Peterborough: Peterborough's upland prehistory. Cambridge: Cambridge Archaeological Unit, Report 369

Lambrick, G., Robinson, M. \& Dodd, A. 2009. The Thames Through Time: The archaeology of the gravel terraces of the Upper and Middle Thames: The Thames Valley in late prehistory, $1500 B C-A D$ 50. Oxford: Oxford University School of Archaeology

Last, J. (ed.) 2007a. Beyond the Grave: New perspectives on barrows. Oxford: Oxbow Books

Last, J. 2007b. Covering old ground: Barrows as closures. In Last 2007a, 156-75

Last, J. 1998. Books of life: Biography and memory in a Bronze Age barrow. Oxford Journal of Archaeology 17(1), 43-53

Løvschal, M. 2014. Emerging boundaries: Social embedment of landscape and settlement divisions in northwestern Europe during the first millennium BC. Current Anthropology 55(6), 725-50

Løvschal, M. 2015. Lines of landscape organisation: Skovbjerg Moraine (Denmark) in the first millennium BC. Oxford Journal of Archaeology 34(3), 259-78

Lucas, G. 2005. The Archaeology of Time. London: Routledge

Martin, E., Pendleton, C., Plouviez, J., Thomas, G. \& Geake, H. 2001. Archaeology in Suffolk 2000. Proceedings of the Suffolk Institute of Archaeology and History 40, 65-109

McOmish, D., Field, D. \& Brown, G. 2002. The Field Archaeology of the Salisbury Plain Training Area. Swindon: English Heritage

Mizoguchi, K. 1993. Time in the reproduction of mortuary practices. World Archaeology 25(2), 223-35

Moore, H. 1995. The problem of origins. Poststructuralism and beyond. In I. Hodder, M. Shanks, A. Alexandri, V. Buchli, J. Carmen, J. Last \& G. Lucas (eds), Interpreting Archaeology: Finding meaning in the past, 51-6. London: Routledge

Mudd, A. 2008. Bronze Age Field System at Tower's Fen, Thorney, Peterborough: Excavations at 'Thorney Borrow Pit' 2004-2005. Oxford: British Archaeological Report 471
Mullin, D. 2003. The Bronze Age Landscape of the Northern English Midlands. Oxford: British Archaeological Report 351

Olivier, L. 2001. Duration, memory and the nature of the archaeological record. In H. Karlsson (ed.), It's About Time: The concept of time in archaeology, 61-70. Goteborg: Bricoleur Press

Olivier, L. 2011. The Dark Abyss of Time: Archaeology and memory. Lanham: AltaMira Press

Patten, R. 2004. Bronze Age and Romano British Activity at Eye Quarry, Peterborough. Cambridge: Cambridge Archaeological Unit, Report 633

Patten, R. 2009. Excavations at Eye Quarry: The southern extension. Cambridge: Cambridge Archaeological Unit, Report 869

Pendleton, C. 1999. Bronze Age Metalwork in Northern East Anglia: A study of its distribution and interpretation. Oxford: British Archaeological Report 279

Pickstone, A. \& Mortimer, R. 2011. The Archaeology of Brigg's Farm, Prior's Fen, Thorney, Peterborough: Archaeological excavation. Cambridge: Oxford Archaeology (East), Report 1094

Pryor, F. 1978. Excavation at Fengate, Peterborough, England: The second report. Toronto: Royal Ontario Museum

Quinnell, H. \& Watts, M. 2002. A Bronze Age cemetery at Elburton, Plymouth. Proceedings of the Devon Archaeological Society 59, 11-43

Richmond, A. \& Coates, G. 2010. Bar Pasture Farm, Pode Hole, Peterborough (Phase 1): Archaeological interim report. Stamford, Lincs: Phoenix Consulting, Report PC259a

Robinson, I. 2007. Middle Bronze Age Cremation Practice in East Anglia: Continuity and change in cemetery form and development. Unpublished MA thesis. University of Cambridge.

Rowlands, M. 1993. The role of memory in the transmission of culture. World Archaeology 25, 141-51

Roymans, N. 1995. The cultural biography of urnfields and the long-term history of a mythical landscape. Archaeological Dialogues 2(1), 2-24

Simpson, W.G. 1976. A barrow cemetery of the second millennium $\mathrm{BC}$ at Tallington, Lincolnshire. Proceedings of the Prehistoric Society 42, 251-39

Spratt, D.A. \& Atherden, M.A. 1993. Prehistoric and Roman Archaeology of North-East Yorkshire. London: Council for British Archaeology Research Report 87

Sturt, F., Garrow, D. \& Bradley, S. 2013. New models of North West European Holocene palaeogeography and inundation. Journal of Archaeological Science 40(11), 3963-76

Taylor, E., Wolfraam-Murray, Y. \& Yates, A. 2011. Archaeological Excavation at Stanground South, Peterborough: Assessment and updated project design. Northampton: Northamptonshire Archaeology, Report $11 / 001$

Taylor, M. 2009. Wood from pits 4437 and 4081. In Daniel 2009, 42

Van Beek, R. \& De Mulder, G. 2014. Circles, cycles and ancestral connotations: The long-term history and 


\section{A. Cooper. ROUND BARROWS IN THE LATER BRONZE AGE OF LOWLAND BRITAIN}

perception of late prehistoric barrows and urnfields in Flanders (Belgium). Proceedings of the Prehistoric Society $80,299-326$

Wake, T. 1942. Some recent archaeological discoveries in Norfolk. Norfolk Archaeology 28, 23-8

Waller, M. 1994. The Fenland Project Number 9: Flandrian environmental change in Fenland. Cambridge: East Anglian Archaeology 70

Whitley, J. 2002. Too many ancestors. Antiquity 76(291), 119-26

Wickstead, H. 2008. Theorising Tenure: Land division and identity in later prehistoric Dartmoor, South-West Britain. Oxford: British Archaeological Report 465

Williams, M. 2003. Growing metaphors: The agricultural cycle as metaphor in the later prehistoric period of Britain and north-western Europe. Journal of Social Archaeology $3(2), 223-55$

Woodward, A. 2000. British Barrows: A matter of life and death. Stroud: Tempus

Yates, D. 2007. Land, Power and Prestige: Bronze Age field systems in Southern England. Oxford: Oxbow Books

Yates, D. \& Bradley, R. 2010a. Still water, hidden depths: The deposition of Bronze Age metalwork in the English Fenland. Antiquity 84(324), 405-15

Yates, D. \& Bradley, R. 2010b. The siting of metalwork hoards in the Bronze Age of south-east England. The Antiquaries Journal 90, 41-72

Young, R. \& Humphrey, J. 1999. Flint use in England after the Bronze Age: Time for a re-evaluation? Proceedings of the Prehistoric Society 65, 231-42

\section{RÉSUMÉ}

'Maintenus en place': Tertres ronds de l'âge du bronze tardif des basses terres de Grande-Bretagne, de Anwen Cooper

Cet article présente une étude systématique des pratiques de l'âge du bronze final dans les tertres ronds, éléments qui sont typiquement considérés comme emblématiques de l'âge du bronze ancien en Grande-Bretagne. Avec l'examen des témoignages de 87 tertres excavés dans l'est de l'Angleterre, il apporte subtilité et détails empiriques aux discussions antérieures sur le rôle changeant des monuments funéraires au cours du IIe millénaire av.J.-C.. Pendant cette période, des activités extrèmement diverses se déroulaient dans les tertres ronds existants. Des inhumations furent ajoutées, les monuments eux-mêmes furent agrandis et reproduits, ils étaient souvent activement construits dans des systèmes de limites de champs et les occupations se trouvaient à proximité. Les trouvailles non seulement attestent de la permanence (bien que changeante) de la signification des tertres ronds à l'âge du bronze tardif. Ils contribuent aussi substantiellement aux débats plus étendus sur le caractère de la vie pendant cette période dans les basses terres britanniques, les relations changeantes entre pratiques 'rituelles' et 'journalières' et les procédés par lesquels des communautés nomades commencèrent à se sédentariser. Plus généralement, cette enquête s'ajoute à une masse croissante de travaux explorant la qualité multi-temporelle des paysages de la fin de la préhistoire.

\section{ZUSSAMENFASSUNG}

,Am Ort festgehalten': Grabhügel in der Spätbronzezeit des britischen Tieflandes, von Anwen Cooper

Dieser Beitrag stellt eine systematische Untersuchung von mit Grabhügeln assoziierten spätbronzezeitlichen Praktiken vor - Elemente, wie sie üblicherweise als emblematisch für die Frühbronzezeit in Großbritannien gelten. Durch die Auswertung der Daten von 87 ausgegrabenen Grabhügeln im östlichen England ergänzt er die bisherige Diskussion zum Bedeutungswandel von Grabmonumenten im Verlauf des 2. Jahrtausends v. Chr. um Feinheiten und empirische Details. Eine große Bandbreite von Aktivitäten wurde in dieser Periode an den vorhandenen Grabhügeln durchgeführt. Bestattungen wurden zugefügt, die Monumente selbst wurden erweitert und vervielfältigt, oft wurden sie aktiv in Landgrenzsysteme eingebaut und Siedlungen wurden in ihrer Nähe angelegt. Diese Beobachtungen bezeugen nicht nur die fortwährende, wenn auch sich verschiebende Bedeutung von Grabhügeln in der späteren Bronzezeit. Sie tragen auch wesentlich zu generelleren Diskussionen über die Lebensweise während dieser Periode im britischen Tiefland bei - die sich verschiebenden Beziehungen zwischen ,rituellen' und ,alltäglichen' Praktiken und die Vorgänge, durch die mobile Gemeinschaften begannen sich niederzulassen. Allgemein gesprochen trägt diese Untersuchung zur wachsenden Zahl an Arbeiten bei, die die multi-temporalen Qualitäten vorgeschichtlicher Landschaften erörtern. 


\section{RESUMEN}

'Contenido en el sitio': los túmulos circulares del Bronce Final de Lowland en Gran Bretaña, por Anwen Cooper

Este artículo presenta el estudio sistemático de las prácticas llevadas a cabo en los túmulos circulares datados en el Bronce Final -estructuras típicas y emblemáticas del Bronce Inicial en Inglaterra. A partir de la información procedente de las excavaciones de 87 túmulos del este de Gran Bretaña, se incorporan algunos aspectos y detalles empíricos a las discusiones previas sobre la modificación de la función de estos monumentos funerarios a lo largo del II milenio BC. En estas estructuras se llevó a cabo una amplia variedad de actividades durante este período. En algunos casos se añadieron enterramientos, o los propios monumentos fueron agrandados y replicados, y a menudo fueron convertidos en elementos de delimitación del espacio, con asentamientos localizados en su entorno. Los hallazgos no sólo demuestran la persistente relevancia -aunque cambiante- de los túmulos en el Bronce Final. También contribuyen sustancialmente a un debate más amplio sobre los modos de vida durante este período en las zonas bajas de Gran Bretaña - los cambios en las relaciones entre prácticas “rituales" y domésticas” y los procesos por los que las comunidades nómadas comienzan a asentarse. Con una perspectiva más amplia, esta investigación se incorpora a un creciente corpus de trabajos que exploran las cualidades multitemporales de los paisajes prehistóricos tardíos. 